\title{
Geochemistry of near-EPR seamounts: importance of source vs. process and the origin of enriched mantle component
}

\author{
Yaoling Niu ${ }^{\mathrm{a}, *}$, Marcel Regelous ${ }^{\mathrm{b}}$, Immo J. Wendt ${ }^{\mathrm{c}}$, Rodey Batiza ${ }^{\mathrm{d}}$, \\ Mike J. O’Hara ${ }^{\text {a }}$ \\ a Department of Earth Sciences, Cardiff University, P.O. Box 914, Park Place, Cardiff CF10 3 YE, UK \\ b Max-Planck-Institut für Chemie, Abteilung Geochemie, Postfach 3060, 55020 Mainz, Germany \\ c Institut für Allgemeine and Angewandte Geologie, Ludwig Maximilian Universität, 80333 Munich, Germany \\ d National Science Foundation, Arlington, VA, 22230, USA
}

Received 4 September 2001; revised version accepted 6 March 2002

\begin{abstract}
Niu and Batiza [Earth Planet. Sci. Lett. 148 (1997) 471-483] show that lavas from the seamounts on the flanks of the East Pacific Rise (EPR) between $5^{\circ}$ and $15^{\circ} \mathrm{N}$ vary from extremely depleted tholeiites to highly enriched alkali basalts. The extent of depletion and enrichment exceeds the known range of seafloor lavas in terms of the abundances and ratios of incompatible elements. New $\mathrm{Sr}-\mathrm{Nd}-\mathrm{Pb}$ isotope data for these lavas show variations $\left({ }^{87} \mathrm{Sr} /\right.$ ${ }^{86} \mathrm{Sr}=0.702362-0.702951 ;{ }^{206} \mathrm{~Pb} / 204 \mathrm{~Pb}=18.080-19.325$ and ${ }^{143} \mathrm{Nd} /{ }^{144} \mathrm{Nd} 0.512956-0.513183$ ) larger than observed in lavas erupted on the nearby EPR axis. These isotopic ratios correlate with each other, with the abundances and ratios of incompatible elements, with the abundances of measured major elements such as $\mathrm{MgO}, \mathrm{CaO}, \mathrm{Na}_{2} \mathrm{O}$ and $\mathrm{TiO}_{2}$ contents, and with the abundances and ratios of major elements corrected for crystal fractionation to $\mathrm{Mg} \#=0.72$ $\left(\mathrm{Ti}_{72}, \mathrm{Al}_{72}, \mathrm{Fe}_{72}, \mathrm{Ca}_{72}, \mathrm{Na}_{72}\right.$, and $\left.\mathrm{Ca}_{72} / \mathrm{Al}_{72}\right)$. These coupled correlations and the spatial distribution of seamounts require an EPR mantle source that has long-term $(>1 \mathrm{Ga}$ ) lithological heterogeneities on very small scales [Niu and Batiza, Earth Planet. Sci. Lett. 148 (1997) 471-483]. Mid-ocean ridge basalt (MORB) major element systematics are, to a great extent, inherited from their fertile sources, which requires caution when using major element data to infer melting conditions. The significant correlations in elemental and isotopic variability (defined as RSD $\%=1 \sigma /$ mean $\times 100$ ) between seamount and axial lavas suggest that both seamount and axial volcanisms share a common heterogeneous mantle source. We confirm previous interpretations [Niu and Batiza, Earth Planet. Sci. Lett. 148 (1997) 471-483; Niu et al., J. Geophys. Res. 104 (1999) 7067-7087] that the geochemical variability of lavas from the broad northern EPR region results from melting-induced mixing of a two-component mantle with the enriched (easily melted) component dispersed as physically distinct domains in a more depleted (refractory) matrix prior to the major melting events. The data also allow the conclusion that recycled oceanic crust cannot explain elevated abundances of elements such as $\mathrm{Ba}, \mathrm{Rb}, \mathrm{Cs}, \mathrm{Th}, \mathrm{U}, \mathrm{K}, \mathrm{Pb}, \mathrm{Sr}$ etc. in enriched MORB and many ocean island basalts. These elements will be depleted in recycled oceanic crust that has passed through subduction zone dehydration reactions. We illustrate that deep portions of recycled oceanic lithosphere are important geochemical reservoirs hosting these and other incompatible elements as a result of metasomatism taking place at the interface between the low velocity zone and the cooling and thickening oceanic lithosphere. (C) 2002 Elsevier Science B.V. All rights reserved.
\end{abstract}

\footnotetext{
* Corresponding author. Tel.: +44-29-2087-6411; Fax: +44-29-2087-4326. E-mail address: niuy@cardiff.ac.uk (Y. Niu).
} 
Keywords: East Pacific Rise; seamounts; mid-ocean ridge basalts; ocean-island basalts; mantle; lateral heterogeneity; metasomatism; low-velocity zones

\section{Introduction}

Mid-ocean ridge basalts (MORB) are produced by decompression melting of mantle material that rises in response to plate separation at ocean ridges. The composition of MORB melts therefore carries information about the nature of the fertile mantle source material and the physical conditions under which MORB melts form. It is generally thought that radiogenic isotopes and incompatible trace elements in MORB reflect the nature and histories of the fertile mantle material, whereas major elements reflect the physical conditions of mantle melting and magma evolution $[3,4]$. This assumption has led to the recognition of MORB mantle compositional heterogeneities on various scales [5-8] and the conjecture that mantle temperature variation [9-11] and plate spreading rate variation $[12,13]$ are the primary controls on the extent and depth of mantle melting, and hence the observed MORB major element compositional variation. While these interpretations are consistent with physical models and some observations [11-14], it is not well known to what extent MORB major element composition indeed reflects the physical conditions of magma genesis or is, alternatively, inherited from fertile mantle source composition [2,4,13,15-22]. Niu et al. [15] have recently demonstrated the mantle compositional controls on MORB chemistry and melting conditions along segments of the Mid-Atlantic Ridge at $33-35^{\circ} \mathrm{N}$, but to generalize this conclusion to all ridges, particularly the fastspreading East Pacific Rise (EPR), requires careful testing. Such tests on EPR axial MORB may prove difficult because some of the needed information may be lost by melt mixing within the mantle during melt aggregation [4,10,11,13,23,24] and mixing/homogenization within crustal magma chambers [25-27]. In contrast, individual off-axis seamounts on the EPR flanks (Fig. 1) represent much smaller melt volumes tapped locally by volcanoes lacking steady-state magma chambers $[7,27,28]$. Consequently, lavas from these sea- mounts are not efficiently mixed, and thus afford promising material to test the relative effect of fertile mantle compositional variation and the effect of physical conditions on MORB compositions.

In this study we present $\mathrm{Sr}, \mathrm{Nd}$ and $\mathrm{Pb}$ isotope data for near-EPR seamounts (Fig. 1) previously studied for major and trace elements [1,29]. Our data indeed show significant correlations among radiogenic isotopes, incompatible trace elements and major elements, which points to lithological controls on the fertile mantle source heterogene-

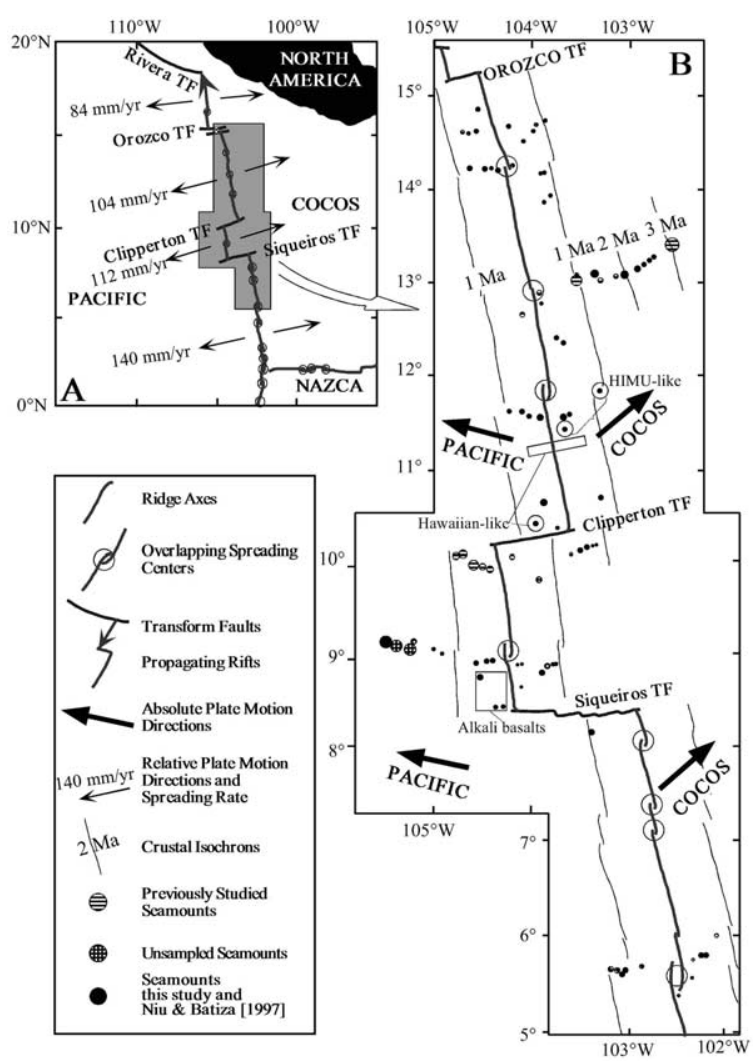

Fig. 1. (A) Tectonic framework of the northern $\left(5^{\circ}-15^{\circ} \mathrm{N}\right)$ EPR and the vicinity. (B) Simplified map of the study area showing the locations of the near-ridge seamounts. The size of the circles approximates the relative size of seamounts. Seamounts and axial locations with HIMU-like, Hawaiianlike and alkali lavas are indicated (see Fig. 4). 
Table 1

$\mathrm{Sr}-\mathrm{Nd}-\mathrm{Pb}$ isotopic data and selected major element and trace element ratios of glass samples from near-ridge seamounts between 5 and $15^{\circ} \mathrm{N}$ EPR

\begin{tabular}{|c|c|c|c|c|c|c|c|c|c|c|c|c|c|c|c|c|c|c|c|}
\hline Sample & Type & $\begin{array}{l}\text { Lati- } \\
\text { tude } \\
\left({ }^{\circ} \mathrm{N}\right)\end{array}$ & $\begin{array}{l}\text { Longi- } \\
\text { tude } \\
\left({ }^{\circ} \mathrm{W}\right)\end{array}$ & $\begin{array}{l}\text { Depth } \\
\text { (m) }\end{array}$ & $\mathrm{MgO}$ & $\mathrm{CaO}$ & $\mathrm{Na}_{2} \mathrm{O}$ & $\mathrm{K}_{2} \mathrm{O}$ & Mg\# & $\frac{\mathrm{CaO}}{\mathrm{Al}_{2} \mathrm{O}}$ & $\mathrm{K} / \mathrm{Ti}$ & $\frac{[\mathrm{La}}{\mathrm{Sm}]_{\mathrm{N}}}$ & {$[\mathrm{Sm} / \mathrm{Yb}]_{\mathrm{N}}$} & ${ }^{87} \mathrm{Sr} /{ }^{86} \mathrm{Sr}$ & ${ }^{143} \mathrm{Nd} /{ }^{144} \mathrm{Nd}$ & $\varepsilon_{\mathrm{Nd}}$ & $\frac{{ }^{206} \mathrm{~Pb}}{{ }^{204} \mathrm{~Pb}}$ & $\frac{{ }^{207} \mathrm{~Pb}}{{ }^{204} \mathrm{~Pb}}$ & $\frac{{ }^{208} \mathrm{~Pb}}{{ }^{204} \mathrm{~Pb}}$ \\
\hline R1-14 & $\mathrm{N}$ & 5.773 & 102.178 & 1834 & 9.35 & 12.76 & 2.29 & 0.04 & 0.69 & 0.78 & 0.05 & 0.44 & 1.03 & $0.702393 \pm 11$ & $0.513148 \pm 14$ & 9.95 & 18.110 & 15.446 & 37.554 \\
\hline R3-1 & $\mathrm{N}$ & 5.782 & 102.213 & 1773 & 9.70 & 12.74 & 2.16 & 0.03 & 0.70 & 0.76 & 0.05 & 0.35 & 0.95 & $0.702458 \pm 13$ & $0.513183 \pm 14$ & 10.63 & 18.080 & 15.421 & 37.516 \\
\hline R3-3 & $\mathrm{N}$ & 5.782 & 102.213 & 1773 & 8.26 & 12.46 & 2.52 & 0.06 & 0.64 & 0.83 & 0.06 & 0.37 & 1.00 & $0.702372 \pm 13$ & - & - & 18.106 & 15.442 & 37.547 \\
\hline R3-4 & E & 5.782 & 102.213 & 1773 & 6.67 & 11.25 & 3.13 & 0.32 & 0.56 & 0.76 & 0.23 & 0.34 & 0.99 & $0.702420 \pm 11$ & $0.513169 \pm 36$ & 10.36 & 18.120 & 15.453 & 37.583 \\
\hline R4-7 & E & 5.602 & 103.017 & 2263 & 6.70 & 11.29 & 3.24 & 0.30 & 0.56 & 0.77 & 0.23 & 1.15 & 1.40 & $0.702589 \pm 10$ & $0.513078 \pm 14$ & 8.58 & 18.485 & 15.491 & 37.974 \\
\hline R7-13 & $\mathrm{N}$ & 8.142 & 103.190 & 2020 & 8.47 & 13.02 & 2.24 & 0.05 & 0.65 & 0.87 & 0.06 & 0.32 & 0.92 & $0.702457 \pm 11$ & $0.513174 \pm 10$ & 10.46 & 18.130 & 15.433 & 37.531 \\
\hline R8-8 & $\mathrm{N}$ & 8.337 & 103.060 & 3180 & 7.13 & 11.92 & 2.67 & 0.11 & 0.56 & 0.84 & 0.10 & 0.64 & 1.08 & $0.702484 \pm 10$ & $0.513131 \pm 10$ & 9.62 & 18.504 & 15.499 & 37.879 \\
\hline R13-1 & Alkali & 8.395 & 104.069 & 2140 & 5.87 & 9.20 & 4.01 & 1.36 & 0.57 & 0.53 & 0.76 & 2.96 & 3.06 & $0.702895 \pm 07$ & $0.512956 \pm 09$ & 6.20 & 18.575 & 15.552 & 38.009 \\
\hline R15-1 & Alkali & 8.757 & 104.537 & 1682 & 6.47 & 8.95 & 3.87 & 1.32 & 0.59 & 0.49 & 0.77 & 2.91 & 3.27 & $0.702877 \pm 10$ & $0.512979 \pm 12$ & 6.65 & 18.683 & 15.545 & 38.076 \\
\hline R16-2 & $\mathrm{N}$ & 8.838 & 104.567 & 2985 & 8.63 & 12.76 & 2.41 & 0.08 & 0.67 & 0.79 & 0.10 & 0.73 & 1.14 & $0.702618 \pm 12$ & $0.513109 \pm 16$ & 9.19 & 18.379 & 15.492 & 37.873 \\
\hline R17-1 & $\mathrm{E}$ & 8.907 & 104.567 & 2715 & 6.29 & 11.12 & 3.28 & 0.70 & 0.55 & 0.74 & 0.44 & 2.00 & 2.06 & $0.702937 \pm 11$ & $0.512993 \pm 08$ & 6.92 & - & - & - \\
\hline R18-3 & E & 8.928 & 104.462 & 2720 & 7.49 & 11.41 & 3.07 & 0.50 & 0.62 & 0.72 & 0.39 & 1.73 & 1.77 & $0.702722 \pm 14$ & $0.513041 \pm 11$ & 7.86 & 18.578 & 15.534 & 38.052 \\
\hline R19-4 & $\mathrm{N}$ & 8.937 & 104.412 & 2267 & 8.64 & 12.95 & 2.47 & 0.08 & 0.67 & 0.81 & 0.10 & 0.64 & 1.22 & $0.702547 \pm 28$ & $0.513128 \pm 16$ & 9.56 & 18.222 & 15.490 & 37.762 \\
\hline R21-6 & E & 8.890 & 104.142 & 2657 & 8.31 & 11.38 & 2.52 & 0.12 & 0.63 & 0.75 & 0.11 & 0.73 & 1.12 & $0.702571 \pm 08$ & $0.513141 \pm 08$ & 9.81 & 18.364 & 15.487 & 37.835 \\
\hline R22-1 & $\mathrm{N}$ & 8.903 & 104.095 & 2749 & 7.95 & 11.22 & 2.45 & 0.08 & 0.62 & 0.76 & 0.08 & 0.60 & 1.15 & $0.702558 \pm 13$ & $0.513138 \pm 09$ & 9.75 & 18.328 & 15.477 & 37.789 \\
\hline R24-5 & $\mathrm{N}$ & 8.965 & 103.870 & 3054 & 6.80 & 10.23 & 2.81 & 0.16 & 0.54 & 0.73 & 0.10 & 0.74 & 1.17 & $0.702560 \pm 10$ & - & - & 18.382 & 15.498 & 37.885 \\
\hline R25-1 & $\mathrm{N}$ & 8.883 & 103.788 & 1980 & 8.37 & 12.48 & 2.61 & 0.09 & 0.65 & 0.80 & 0.10 & 0.61 & 1.15 & $0.702432 \pm 11$ & $0.513144 \pm 08$ & 9.87 & 18.280 & 15.489 & 37.790 \\
\hline R28-7 & $\mathrm{N}$ & 8.812 & 103.900 & 1984 & 8.72 & 12.41 & 2.41 & 0.06 & 0.66 & 0.78 & 0.07 & 0.51 & 1.13 & $0.702585 \pm 10$ & $0.513139 \pm 09$ & 9.77 & 18.381 & 15.503 & 37.891 \\
\hline R31-1 & E & 9.088 & 105.018 & 2366 & 8.52 & 12.47 & 2.42 & 0.12 & 0.65 & 0.79 & 0.14 & 0.75 & 1.09 & $0.702362 \pm 11$ & $0.513147 \pm 08$ & 9.93 & 18.316 & 15.500 & 37.860 \\
\hline R32-1 & E & 9.085 & 104.923 & 3025 & 8.63 & 11.64 & 2.74 & 0.34 & 0.68 & 0.70 & 0.32 & 1.57 & 1.60 & $0.702876 \pm 15$ & $0.513047 \pm 09$ & 7.98 & 18.533 & 15.515 & 38.071 \\
\hline R60-1 & $\mathrm{N}$ & 10.002 & 104.913 & 2640 & 9.62 & 11.87 & 2.88 & 0.09 & 0.70 & 0.67 & 0.10 & 0.70 & 1.35 & $0.702512 \pm 11$ & $0.513173 \pm 08$ & 10.44 & 18.343 & 15.489 & 37.749 \\
\hline R62-7 & E & 10.025 & 104.188 & 2320 & 8.89 & 12.08 & 2.78 & 0.11 & 0.67 & 0.74 & 0.12 & 0.73 & 1.25 & $0.702420 \pm 10$ & $0.513153 \pm 08$ & 10.05 & 18.302 & 15.482 & 37.710 \\
\hline R65-1 & $\mathrm{N}$ & 10.130 & 103.407 & 2074 & 8.82 & 12.48 & 2.41 & 0.07 & 0.68 & 0.74 & 0.10 & 0.63 & 1.02 & $0.702414 \pm 10$ & $0.513111 \pm 09$ & 9.23 & 18.138 & 15.441 & 37.545 \\
\hline R66-1 & $\mathrm{N}$ & 10.140 & 103.340 & 2600 & 9.18 & 12.27 & 2.46 & 0.07 & 0.68 & 0.75 & 0.09 & 0.51 & 1.03 & $0.702513 \pm 13$ & $0.513178 \pm 11$ & 10.53 & 18.147 & 15.463 & 37.630 \\
\hline R71-21 & $\mathrm{N}$ & 10.263 & 103.735 & 3380 & 5.05 & 8.67 & 3.46 & 0.24 & 0.39 & 0.68 & 0.09 & 0.70 & 1.24 & $0.702541 \pm 13$ & $0.513154 \pm 09$ & 10.07 & - & - & - \\
\hline R72-2 & E & 10.378 & 103.928 & 2748 & 8.84 & 11.18 & 2.92 & 0.23 & 0.66 & 0.66 & 0.24 & 1.12 & 1.33 & $0.702748 \pm 13$ & - & - & 18.133 & 15.484 & 37.535 \\
\hline R73-1 & E & 10.377 & 103.923 & 2547 & 8.50 & 11.33 & 2.98 & 0.26 & 0.65 & 0.67 & 0.25 & 1.22 & 1.33 & $0.702694 \pm 10$ & $0.513094 \pm 07$ & 8.90 & 18.135 & 15.488 & 37.551 \\
\hline R73-1 rep & & & & & & & & & & & & & & & & & 18.136 & 15.489 & 37.551 \\
\hline R74-1 & $\mathrm{N}$ & 10.618 & 103.843 & 2320 & 9.31 & 12.83 & 2.03 & 0.03 & 0.68 & 0.85 & 0.04 & 0.31 & 0.85 & $0.702439 \pm 11$ & - & - & 18.276 & 15.489 & 37.759 \\
\hline R78-6 & $\mathrm{E}$ & 11.217 & 103.583 & 2450 & 7.66 & 10.48 & 3.33 & 0.80 & 0.66 & 0.61 & 0.73 & 3.73 & 1.72 & $0.702922 \pm 10$ & $0.512970 \pm 09$ & 6.48 & 19.305 & 15.607 & 38.996 \\
\hline R79-2 & E & 11.790 & 103.245 & 1620 & 7.61 & 11.36 & 3.20 & 0.81 & 0.65 & 0.66 & 0.87 & 3.54 & 1.76 & $0.7029 \pm 14$ & - & - & 19.308 & 15.600 & 39.016 \\
\hline R80-1 & E & 11.802 & 103.252 & 1619 & 8.25 & 11.03 & 3.26 & 0.49 & 0.67 & 0.61 & 0.40 & 1.85 & 1.66 & $0.702529 \pm 08$ & - & - & 18.400 & 15.489 & 37.903 \\
\hline R83-3 & E & 11.235 & 103.593 & 2900 & 8.08 & 10.24 & 3.29 & 0.71 & 0.64 & 0.64 & 0.50 & 2.50 & 1.64 & $0.702843 \pm 13$ & $0.513012 \pm 11$ & 7.30 & 19.035 & 15.585 & 38.689 \\
\hline R83-3rep & & & & & & & & & & & & & & & - & & 19.034 & 15.583 & 38.638 \\
\hline R89 SG & E & 11.518 & 103.877 & 2455 & 7.47 & 11.74 & 3.20 & 0.20 & 0.61 & 0.76 & 0.15 & 0.85 & 1.42 & $0.702498 \pm 11$ & $0.51316 \pm 10$ & 10.18 & 18.260 & 15.472 & 37.638 \\
\hline
\end{tabular}




\begin{tabular}{|c|c|c|c|c|c|c|c|c|c|c|c|c|c|c|c|c|c|c|c|}
\hline Sample & Type & $\begin{array}{l}\text { Lati- } \\
\text { tude } \\
\left({ }^{\circ} \mathrm{N}\right)\end{array}$ & $\begin{array}{l}\text { Longi- } \\
\text { tude } \\
\left({ }^{\circ} \mathrm{W}\right)\end{array}$ & $\begin{array}{l}\text { Depth } \\
\text { (m) }\end{array}$ & $\mathrm{MgO}$ & $\mathrm{CaO}$ & $\mathrm{Na}_{2} \mathrm{O}$ & $\mathrm{K}_{2} \mathrm{O}$ & $\mathrm{Mg} \#$ & $\frac{\mathrm{CaO}}{\mathrm{Al}_{2} \mathrm{O}_{3}}$ & $\mathrm{~K} / \mathrm{Ti}$ & $\frac{[\mathrm{La}}{\mathrm{Sm}]_{\mathrm{N}}}$ & {$[\mathrm{Sm} / \mathrm{Yb}]_{\mathrm{N}}$} & ${ }^{87} \mathrm{Sr} /{ }^{86} \mathrm{Sr}$ & ${ }^{143} \mathrm{Nd} /{ }^{144} \mathrm{Nd}$ & $\varepsilon_{\mathrm{Nd}}$ & $\frac{{ }^{206} \mathrm{~Pb}}{{ }^{204} \mathrm{~Pb}}$ & $\frac{{ }^{207} \mathrm{~Pb}}{{ }^{204} \mathrm{~Pb}}$ & $\frac{{ }^{208} \mathrm{~Pb}}{{ }^{204} \mathrm{~Pb}}$ \\
\hline R89 SGrep & & & & & & & & & & & & & & & - & & 18.266 & 15.478 & 37.603 \\
\hline R102-1 & E & 13.217 & 102.682 & 2350 & 8.04 & 11.97 & 2.71 & 0.11 & 0.64 & 0.76 & 0.11 & 0.72 & 1.19 & $0.702530 \pm 10$ & $0.513143 \pm 09$ & 9.85 & 18.351 & 15.495 & 37.818 \\
\hline R103-3 & $\mathrm{N}$ & 13.837 & 103.797 & 2870 & 7.74 & 11.83 & 3.03 & 0.07 & 0.63 & 0.78 & 0.07 & 0.57 & 1.27 & $0.702553 \pm 11$ & - & - & 18.182 & 15.470 & 37.716 \\
\hline R109-5 & E & 14.153 & 104.302 & 2610 & 7.79 & 12.10 & 2.66 & 0.48 & 0.65 & 0.76 & 0.46 & 2.03 & 1.59 & $0.702622 \pm 13$ & - & - & 18.682 & 15.510 & 38.133 \\
\hline R110-4 & E & 14.142 & 104.357 & 2760 & 5.75 & 9.93 & 3.64 & 0.52 & 0.52 & 0.68 & 0.31 & 1.59 & 1.45 & $0.702719 \pm 13$ & $0.513111 \pm 19$ & 9.23 & 18.496 & 15.495 & 37.955 \\
\hline
\end{tabular}

Selected major elements $\left(\mathrm{wt}^{2} \%\right)$ and trace element ratios are taken from [1] Rock type: N, N-MORB $(\mathrm{K} / \mathrm{Ti}<0.11)$; E, E-MORB $(\mathrm{K} / \mathrm{Ti}>0.11)$; and alkali basalts with $\mathrm{K}_{2} \mathrm{O}>1 \mathrm{wt} \%$. Sr, $\mathrm{Nd}$ and $\mathrm{Pb}$ isotope analyses were done on fresh, hand-picked glasses, lightly leached at room temperature in $\mathrm{HCl}-\mathrm{H}_{2} \mathrm{O}_{2}$ for a few minutes to remove $\mathrm{Mn}$ oxides in possible micro-fractures and other potentially labile contaminants. The samples were then washed ultrasonically in Milli-Q water before digestion in $\mathrm{HF}-\mathrm{HNO}_{3} . \mathrm{Pb}$ was separated from the rock matrix using standard $\mathrm{HBr}-\mathrm{HCl}$ procedures. The $\mathrm{Sr}$ and $\mathrm{Nd}$ fraction from the $\mathrm{Pb}$ ion exchange columns was collected, and $\mathrm{Sr}$ and the REE were separated on cation exchange columns in dilute HCl. Nd was then separated from the other REE using HDEHP ion exchange columns. Blanks were below $0.7 \mathrm{ng}$ for $\mathrm{Sr}$ and less than $0.4 \mathrm{ng}$ for $\mathrm{Nd}$, and the total $\mathrm{Pb}$ procedure blank was between 60 and 100 pg per analysis. Isotope measurements were carried out in static mode on a Fisons-VG-Micromass Sector 54-30 multicollector mass spectrometer. Pb was loaded on single Re filaments in a $\mathrm{H}_{3} \mathrm{PO}_{4}$-silica gel mixture, and analyzed at $1350^{\circ} \mathrm{C}$. The data were corrected for mass fractionation using the values of [88] for the $\mathrm{NBS} 981 \mathrm{~Pb}$ standard. Sr was loaded in $1 \mathrm{~N} \mathrm{H}_{3} \mathrm{PO}_{4}$ on single Ta filaments, and $\mathrm{Nd}$ loaded in a dilute $\mathrm{HNO}_{3}-\mathrm{H}_{3} \mathrm{PO}_{4}$ mixture on a triple Ta-Re-Ta filament assembly. For Sr and $\mathrm{Nd}$ isotope measurements, exponential fractionation corrections were applied using ${ }^{86} \mathrm{Sr} /{ }^{88} \mathrm{Sr}=0.1194$ and ${ }^{146} \mathrm{Nd} /{ }^{144} \mathrm{Nd}=0.7219$. The NBS $987 \mathrm{Sr}$ standard and an Ames ${ }^{\circledR} \mathrm{Nd}$ metal standard gave ${ }^{87} \mathrm{Sr} /{ }^{86} \mathrm{Sr}=0.710259 \pm 15(2 \sigma)$ and ${ }^{143} \mathrm{Nd} /{ }^{144} \mathrm{Nd}=0.511962 \pm 11(2 \sigma)$, respectively, during the course of this study. $\mathrm{Nd}$ isotopic ratios have been normalized to values of 0.710248 for NBS 987, and 0.511971 for the Nd standard (corresponding to a value of 0.511855 for the La Jolla standard). Detailed sample preparation and analytical details can be found in $[31,32]$ 
ities, and stresses the need for caution when using lava major element data to estimate the extent and depth of melting. The data also allow us to show that recycled oceanic crust cannot explain the enriched geochemical signatures observed in enriched MORB and ocean island basalts.

\section{Samples, sample locations and analytical details}

The samples were dredged during the 1988 Raitt 02 expedition aboard R/V Thomas Washington $[29,30]$. They were collected from near-ridge seamounts within the $1 \mathrm{Ma}$ isochron $(<\sim 60 \mathrm{~km})$ of the EPR axis between $5^{\circ}$ and $15^{\circ} \mathrm{N}$ on both the Pacific and Cocos Plates (Fig. 1). These samples have been previously studied for major and trace elements [1,24,29,30]. Subsets of these samples that cover the entire compositional spectrum defined by trace elements are studied here for $\mathrm{Sr}-$ $\mathrm{Nd}-\mathrm{Pb}$ isotopes. The data are presented in Table 1. Sample preparation and analytical details for major and trace elements of the seamount lavas are given in [1] with additional sample descriptions given in [29]. Analytical procedure for $\mathrm{Sr}-$ $\mathrm{Nd}-\mathrm{Pb}$ isotopic data acquisition is detailed in $[31,32]$ and is also described briefly in the note to Table 1.

\section{Data and interpretations}

\subsection{Differences and similarities between EPR seamount and axial lavas}

Fig. 2 compares several petrologic and geochemical parameters in the form of histograms between EPR seamount lavas and lavas erupted at the nearby axis (Fig. 1). We confirm previous observations $[28,29]$ that seamount lavas are on average more primitive (i.e., higher eruption temperatures, higher $\mathrm{Mg \#} \mathrm{etc.)} \mathrm{and} \mathrm{compositionally}$ more diverse (e.g., greater variability expressed as $\mathrm{RSD} \%$ in $\mathrm{K} / \mathrm{Ti}$ and ${ }^{87} \mathrm{Sr} /{ }^{86} \mathrm{Sr}$ ratios) than axial lavas. The approximately normal distribution of eruption temperatures and $\mathrm{Mg \#}$ for both seamount and axial lavas is consistent with cooling at crustal levels being the primary control on evo-

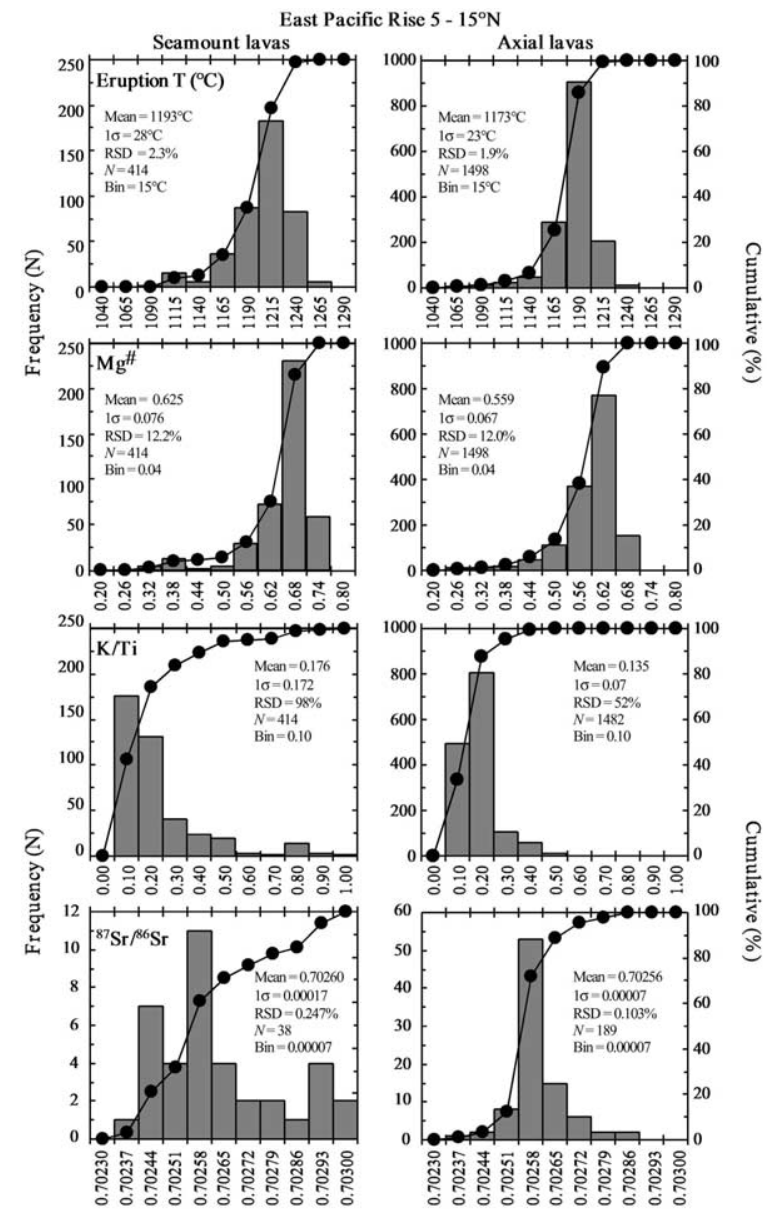

Fig. 2. Histograms of eruption temperature $\left({ }^{\circ} \mathrm{C}\right.$, $\left.T_{\text {liquidus }}=1026 \mathrm{e}^{\left[0.01894 \mathrm{MgO}\left(\mathrm{wt}^{\%} \%\right)\right.}\right)[67], \mathrm{Mg} \#\left(\mathrm{Mg} /\left[\mathrm{Mg}+\mathrm{Fe}^{2+}\right]\right), \mathrm{K} /$ $\mathrm{Ti}$ and ${ }^{87} \mathrm{Sr} /{ }^{86} \mathrm{Sr}$ to compare the differences and similarities between seamount and axial lavas at $5^{\circ}$ to $15^{\circ} \mathrm{N}$ EPR. Seamount data are from $[1,29]$, this study and unpublished data of Y. Niu and R. Batiza. Axial data are from $[2,8,19,27$, 30,31] and unpublished data of Y. Niu and R. Batiza.

lution, phase equilibria and major element composition of MORB melts [26,33,34]. If $\sim 1180^{\circ} \mathrm{C}$ marks the onset of clinopyroxene crystallization at low pressure [35], then $>73 \%$ seamount lavas have only experienced troctolite fractionation at $T_{\text {liquidus }}>1180^{\circ} \mathrm{C}$, whereas $>60 \%$ axial lavas have undergone some gabbro fractionation at $T_{\text {liquidus }}<1180^{\circ} \mathrm{C}$. This has first-order implications for the structure of ocean crust formed at the EPR and the building of the near-EPR seamounts. As shallow level cooling and fractiona- 


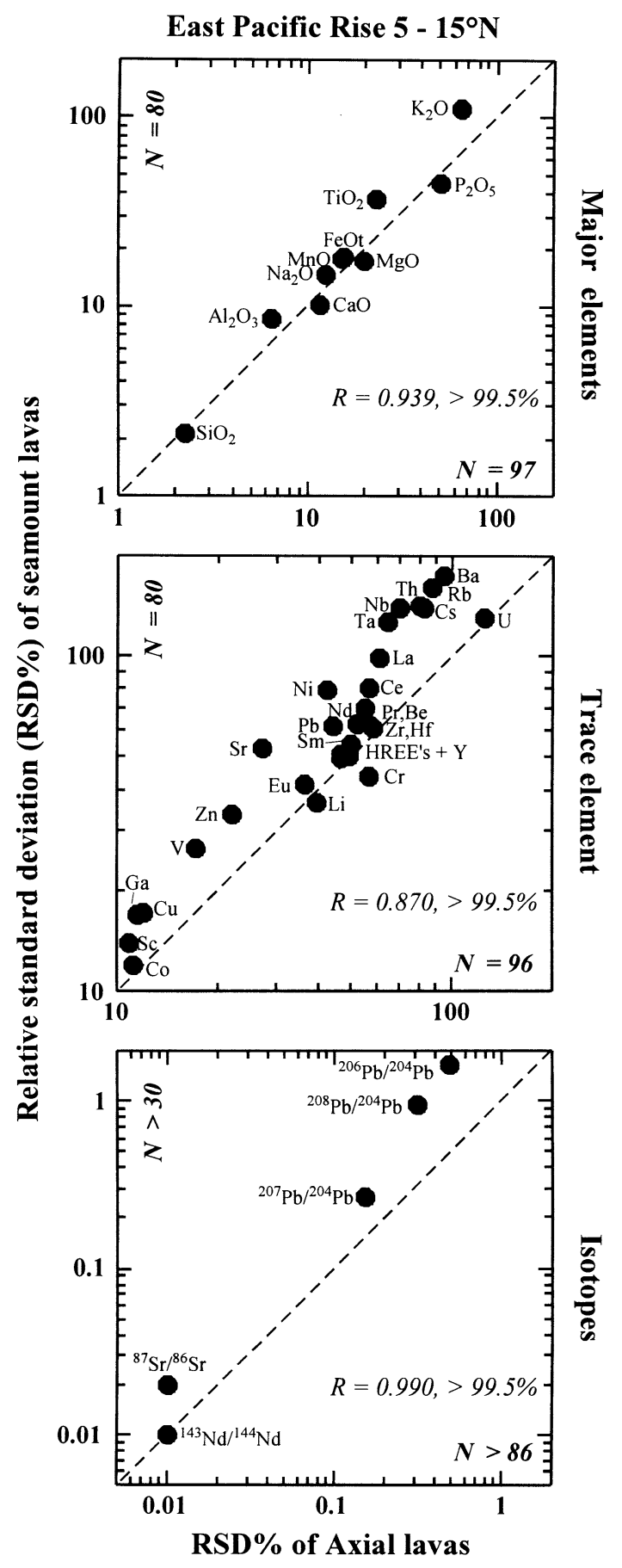

tion cannot change $\mathrm{K} / \mathrm{Ti}$ and ${ }^{87} \mathrm{Sr} /{ }^{86} \mathrm{Sr}$ significantly without evidence for obvious assimilation, these parameters primarily reflect fertile source signals. The similar means of the two parameters between seamount and axial lavas suggest a similarly heterogeneous source, but the very different RSD values result from different degrees of postmelting processes (see below).

Fig. 3 compares the variability of major elements, trace elements and isotopes between seamount and axial lavas. The significant linear correlations on these plots are consistent with a similarly heterogeneous fertile source for both seamount and axial volcanisms. The overall smaller $\mathrm{RSD} \%$ of axial lavas relative to seamount lavas results from the action of two mixing processes: (1) aggregation and migration of melt produced in a large mantle volume towards the very narrow axial zone of crust accretion $[4,23,24]$ and (2) homogenization in crustal magma chambers [25-27] that exist beneath the EPR axis [26,27,30,31]. Both these processes are less pronounced beneath individual seamounts $[24,28,29]$.

\subsection{Correlations among $\mathrm{Sr}-\mathrm{Nd}-\mathrm{Pb}$ isotopic ratios}

Fig. 4 shows that the seamount lavas define linear trends in $\mathrm{Nd}-\mathrm{Sr}$ and $\mathrm{Pb}-\mathrm{Pb}$ isotope spaces with the enriched ends surpassing the most enriched EPR axial lavas. The trends in $\mathrm{Pb}-\mathrm{Sr}$ spaces are also mostly linear with the complications caused by the two alkali lavas (R13-1 and 15-2; Fig. 1) and two samples (R72-2, 73-1; Fig. 1) that lie within the trend defined by the $11^{\circ} 20^{\prime} \mathrm{N}$ axial lavas (in the dashed rectangles) that are interpreted to be genetically related to Hawaiian mantle plume materials [2]. Data of northern

Fig. 3. Comparison of elemental and isotopic variability between seamount and axial lavas in terms of relative standard deviation $\left(\mathrm{RSD}_{0}=1 \sigma /\right.$ mean $\left.\times 100\right)$. The significant linear correlations suggest that both seamount and axial volcanisms share a similar heterogeneous source. Log-log scales are used to show details. The 1:1 lines are plotted for reference. Data sources are as in Fig. 2, but for major element comparison, only samples with ICP-MS trace element data are used. 
EPR axial lavas [2,19,31] and the extremely depleted lavas from the Garrett transform [32] are plotted for comparison. To a first order, the EPR isotope data can be interpreted as resulting from mixing between an enriched component defined by the HIMU-like seamount lavas (R78-6, 79-2 and 83-3; Fig. 1) and ultra-depleted Garrett transform lavas. This is consistent with the interpretation that the lavas from the broad northern EPR region result from melting-induced mixing of a two-component mantle with the enriched component dispersed as physically distinct domains in more depleted matrix $[1,2]$.

Note that the concept of 'melting-induced mixing of a two component mantle' emphasizes the physical state of the enriched component as easily melted domains (e.g., rich in alkalis, volatiles and other incompatible elements) relative to the more depleted and refractory matrix, which, upon melting, produces melts with apparent mixing trends on geochemical diagrams. Both the enriched component and the depleted matrix can in fact be isotopically heterogeneous. For example, while the Garrett transform lavas are overall isotopically depleted, the large variation range that exceeds the analytical errors is likely due to local lithological variations in the same region. The enriched component must in fact have different origins with different isotopic signatures. For example, both HIMU-like lavas and alkali lavas (R131 and 15-2; Fig. 1) have high ${ }^{87} \mathrm{Sr} /{ }^{86} \mathrm{Sr}$ and low ${ }^{143} \mathrm{Nd} /{ }^{144} \mathrm{Nd}$, but they do not consistently lie at the most enriched end in all isotopic spaces. The alkali lavas do not have the most radiogenic $\mathrm{Pb}$ and the HIMU-like lavas do not have high enough ${ }^{207} \mathrm{~Pb} /{ }^{204} \mathrm{~Pb}$ given their high ${ }^{206} \mathrm{~Pb} /{ }^{204} \mathrm{~Pb}$ and ${ }^{208} \mathrm{~Pb} /{ }^{204} \mathrm{~Pb}$ to be simple enriched endmembers in some isotope spaces. The $11^{\circ} 20^{\prime} \mathrm{N}$ axial lavas [2] including the two seamount samples (R72-2, 73-1), for example, are of different origin as discussed above. Nevertheless, the first order correlations defined by the majority of the data in all these isotope plots are robust and indicate that both the enriched component and the depleted matrix are ancient and have developed their isotopic signatures independently.

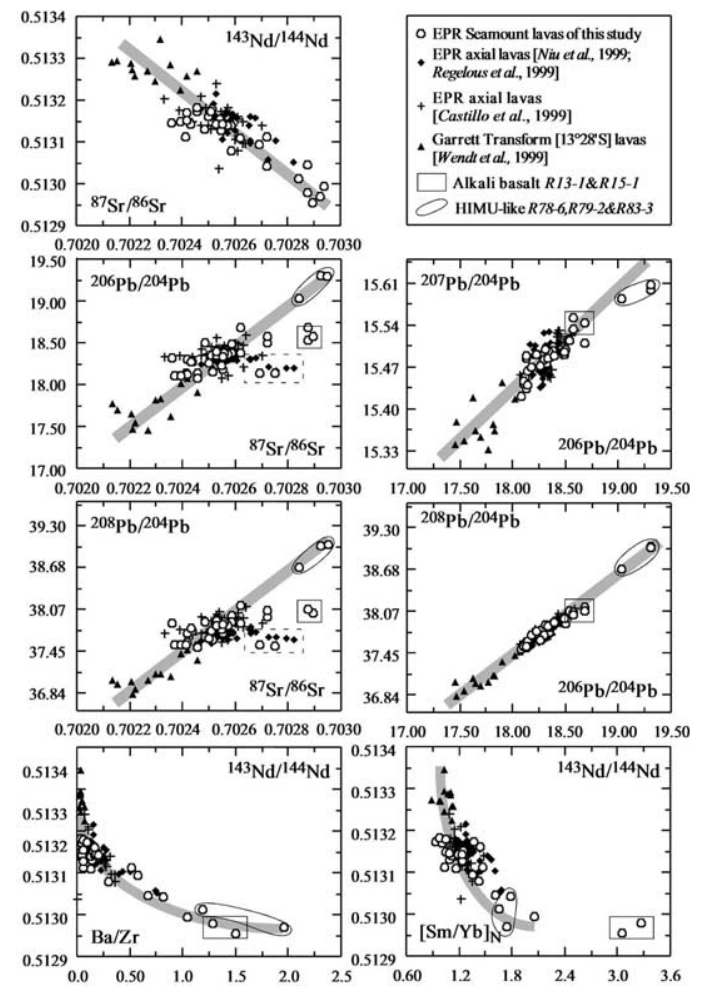

Fig. 4. Plots of seamount lavas in $\mathrm{Sr}-\mathrm{Nd}-\mathrm{Pb}$ isotopic spaces and correlations of these isotopic ratios with ratios of highly to moderately incompatible elements (e.g., $\mathrm{Ba} / \mathrm{Zr}$ ) and moderately to weakly incompatible elements (e.g., $\mathrm{Sm} / \mathrm{Yb}$; subscript ' $N$ ' refers to values normalized to chondrite). Axial lavas and the most depleted lavas from the Garrett transform are plotted for comparison. Data from other locations along the EPR have similar ranges, and thus are not plotted for clarity. Note the Hawaiian-like lavas (dashed rectangles: R72-2 and R73-1) [2] (see Fig. 1 for locations). More plots can be found in the Background Data Set $^{1}$.

\subsection{Correlations of $\mathrm{Sr}-\mathrm{Nd}-\mathrm{Pb}$ isotopic ratios with ratios of incompatible elements}

Fig. 4 plots ${ }^{143} \mathrm{Nd} /{ }^{144} \mathrm{Nd}$ against ratios of highly to moderately incompatible elements (e.g., $\mathrm{Ba} / \mathrm{Zr}$ ) and ratios of moderately to weakly incompatible elements (e.g., Sm/Yb; see Background Data Set ${ }^{1}$ for more plots). Ratios of $\mathrm{Rb} / \mathrm{Sr}, \mathrm{U} / \mathrm{Pb}$ and $\mathrm{Th} / \mathrm{Pb}$ would be more illustrative, but the analyses of

\footnotetext{
1 http://www.elsevier.com/locate/epsl
} 

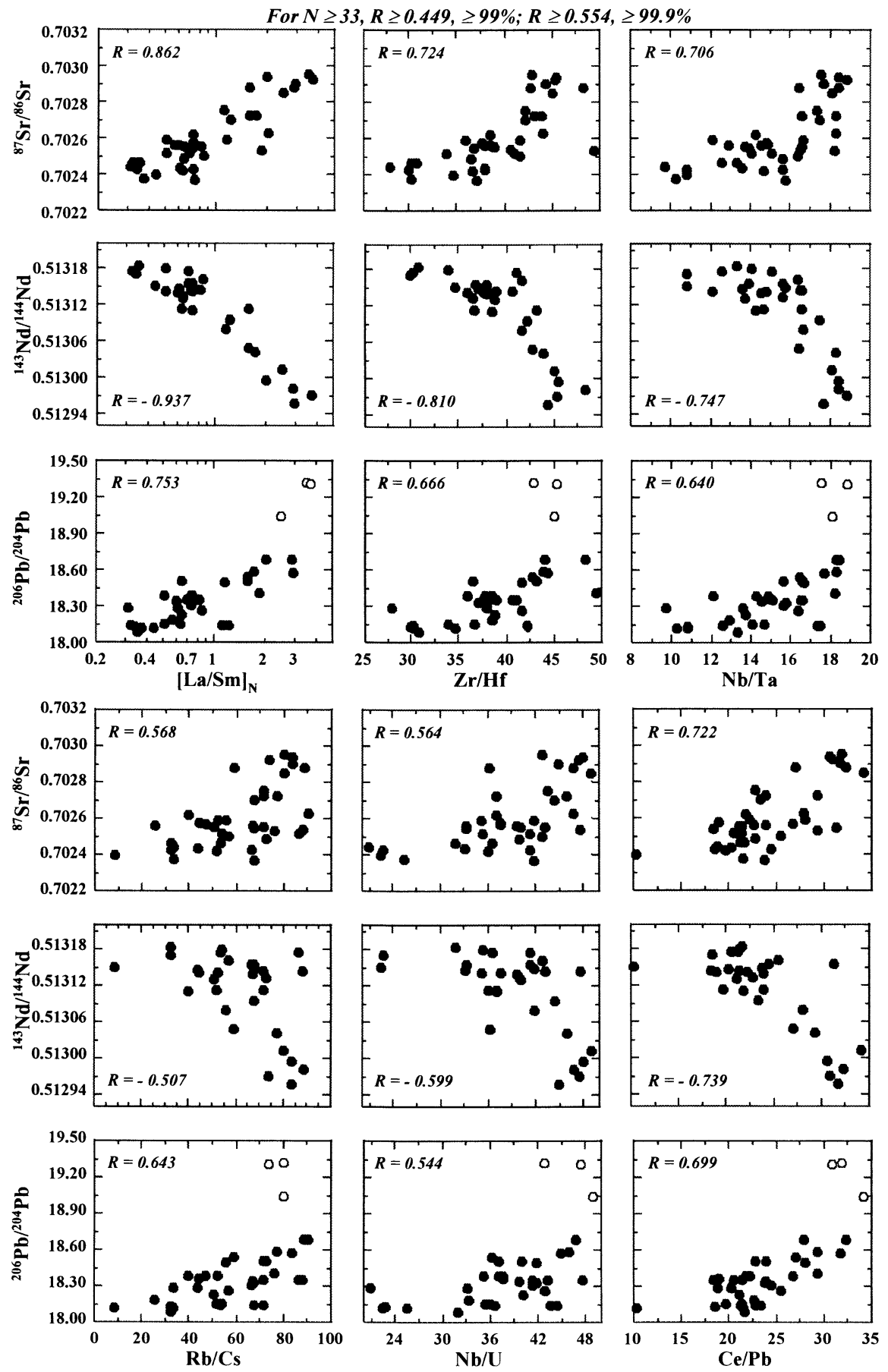

Fig. 5. Plots of $\mathrm{Sr}-\mathrm{Nd}-\mathrm{Pb}$ isotopic ratios with ratios of incompatible elements in seamount lavas. The significant correlations of isotopes with $[\mathrm{La} / \mathrm{Sm}]_{\mathrm{N}}$ is expected. The scattered, yet statistically significant correlations of isotopic ratios with ratios of geochemically similar elements such as $\mathrm{Zr} / \mathrm{Hf}, \mathrm{Nb} / \mathrm{Ta}, \mathrm{Rb} / \mathrm{Cs}, \mathrm{Nb} / \mathrm{U}$ and $\mathrm{Ce} / \mathrm{Pb}$ are reported here for the first time. Note that correlation coefficients in panels involving $\mathrm{Pb}$ isotopes do not include the three HIMU-like samples (open circles). More plots can be found in the Background Data Set ${ }^{1}$. 


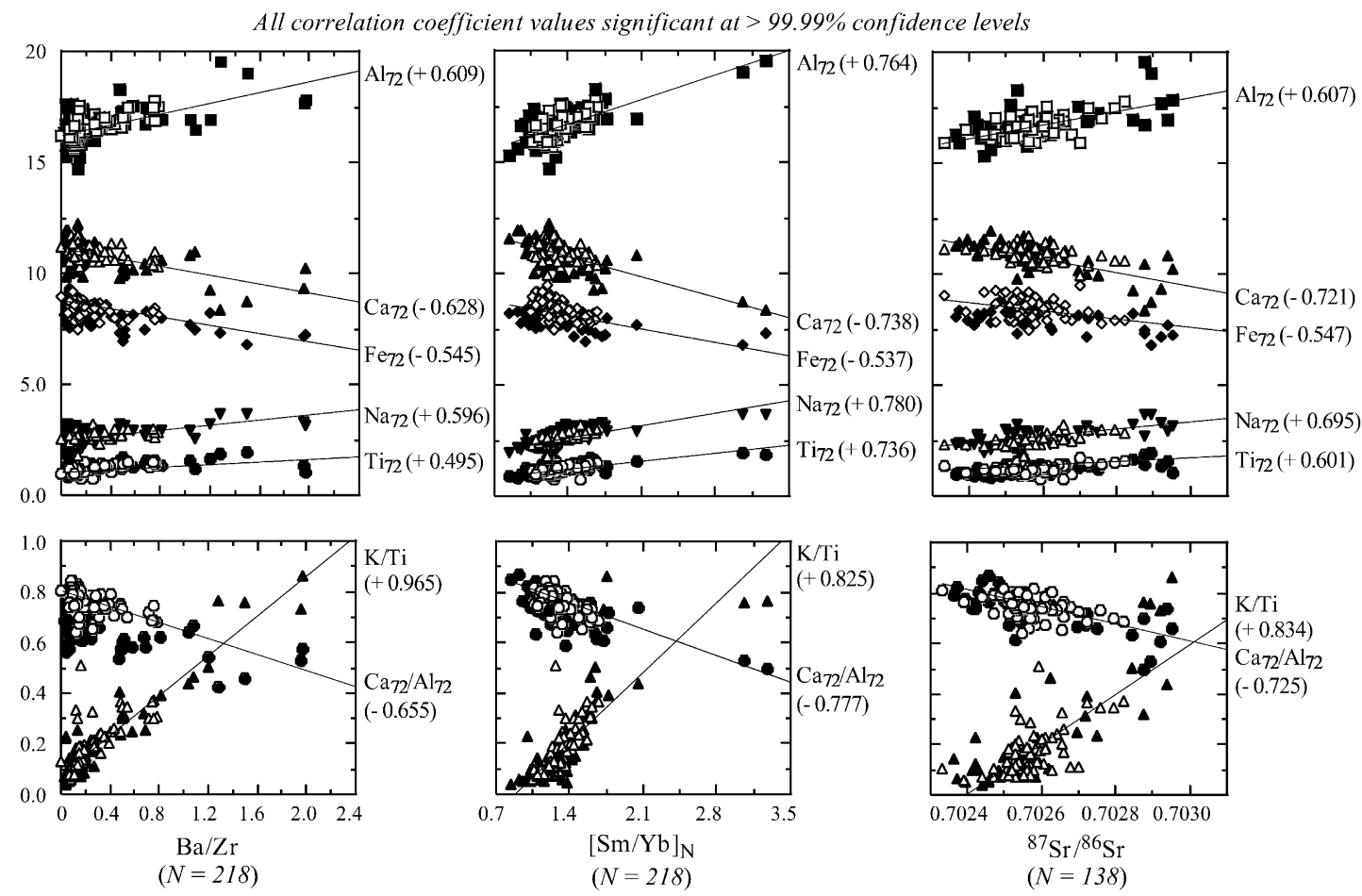

Fig. 6. Plots of $\mathrm{K} / \mathrm{Ti}$ and abundances and ratios of major elements after correction for crystal fractionation to $\mathrm{Mg \#}=0.72$ (see [2] for procedure) against $\mathrm{Ba} / \mathrm{Zr},[\mathrm{Sm} / \mathrm{Yb}]_{\mathrm{N}}$ and ${ }^{87} \mathrm{Sr} /{ }^{86} \mathrm{Sr}$. Seamount data (from [1] and this study) are in solid symbols. Axial data (open symbols) $[2,19,31]$ are also plotted for comparison. The values in parentheses are correlation coefficients for seamount data only. Note that both seamount and axial lavas define the same trends on all these plots.

axial samples published in [19] do not include $\mathrm{Rb}$, $\mathrm{U}, \mathrm{Th}$ and $\mathrm{Pb}$ data. The scatter and complexity in Fig. 4 are expected given the discussion above, but the negative trends of $\mathrm{Ba} / \mathrm{Zr}$ and $[\mathrm{Sm} / \mathrm{Yb}]_{\mathrm{N}}$ with ${ }^{143} \mathrm{Nd} /{ }^{144} \mathrm{Nd}$ substantiate the interpretation that radiogenic isotopes are supported by parent/daughter ratios of the source materials. This again demonstrates that the enriched component and depleted matrix are both ancient $(>1 \mathrm{Ga})$ having their own parent/daughter element ratios, and having developed their isotopic signatures independently. The shaded thick curves in these plots approximate the melting-induced mixing trends, which explain most of the data except for the two alkali basalts distinct on plots involving $[\mathrm{Sm} / \mathrm{Yb}]_{\mathrm{N}}$. These two samples are apparently 'escaped' very low degree melts with strong garnet signatures, comprising the highest $\mathrm{Sm} / \mathrm{Yb}$ and lowest Sc (18 and $24 \mathrm{ppm}$ respectively) among all the northern EPR samples.
Fig. 5 plots $\mathrm{Sr}-\mathrm{Nd}-\mathrm{Pb}$ isotopic ratios against $[\mathrm{La} / \mathrm{Sm}]_{\mathrm{N}}, \mathrm{Zr} / \mathrm{Hf}, \mathrm{Nb} / \mathrm{Ta}, \mathrm{Rb} / \mathrm{Cs}, \mathrm{Nb} / \mathrm{U}$ and $\mathrm{Ce} /$ $\mathrm{Pb}$ for seamount lavas only. The correlations of $[\mathrm{La} / \mathrm{Sm}]_{\mathrm{N}}$ with radiogenic isotopes are expected. However, significant correlations of $\mathrm{Sr}-\mathrm{Nd}-\mathrm{Pb}$ isotopic ratios with $\mathrm{Zr} / \mathrm{Hf}, \mathrm{Nb} / \mathrm{Ta}, \mathrm{Rb} / \mathrm{Cs}, \mathrm{Nb} / \mathrm{U}$ and $\mathrm{Ce} / \mathrm{Pb}$ have not been reported. These correlations confirm the inference $[1,2]$ that the element in the numerator is more incompatible than the element in the denominator for these element pairs. Caution is thus necessary when using $\mathrm{Nb} /$ $\mathrm{U}$ and $\mathrm{Ce} / \mathrm{Pb}$ ratios to interpret ocean floor petrogenesis and crust-mantle differentiation [36]. Also, while some recent experiments [37] have shown $D_{\mathrm{Zr}} / D_{\mathrm{Hf}} \approx 0.5$, and probably also $D_{\mathrm{Nb}} /$ $D_{\mathrm{Ta}} \approx 0.5$ in mafic anhydrous melt systems, the apparent $D_{\mathrm{Rb}}<D_{\mathrm{Cs}}$ suggested in Fig. 5 (also see [1]) is unexpected [38]. Therefore, further investigations are needed. Note that while the observed $D_{\mathrm{Zr}}<D_{\mathrm{Hf}}, \quad D_{\mathrm{Nb}}<D_{\mathrm{Ta}}, \quad D_{\mathrm{Rb}}<D_{\mathrm{Cs}}, \quad D_{\mathrm{Nb}}<D_{\mathrm{U}}$, 
and $D_{\mathrm{Ce}}<D_{\mathrm{Pb}}$ [1] are correct, the significant correlations of ratios of these paired elements with isotopes in Fig. 5 suggest that the observed variations of these ratios in seamount and axial lavas are largely inherited from the heterogeneous fertile source, not produced by the major melting events. In other words, $\mathrm{Zr} / \mathrm{Hf}, \mathrm{Nb} / \mathrm{Ta}, \mathrm{Rb} / \mathrm{Cs}$, $\mathrm{Nb} / \mathrm{U}$ and $\mathrm{Ce} / \mathrm{Pb}$ ratios are high in the enriched component but low in the depleted matrix [1].

\subsection{Correlations of $\mathrm{Sr}-\mathrm{Nd}-\mathrm{Pb}$ isotopic ratios, incompatible element ratios and the abundances and ratios of major elements corrected for crystal fractionation}

Fig. 6 shows that the data from both seamount and axial lavas $[2,19,31]$ exhibit statistically significant correlations among ${ }^{87} \mathrm{Sr} /{ }^{86} \mathrm{Sr}$ (also $\mathrm{Nd}$ and $\mathrm{Pb}$ isotopes not shown), $\mathrm{Ba} / \mathrm{Zr},[\mathrm{Sm} / \mathrm{Yb}]_{\mathrm{N}}$, and abundances and ratios of major and minor elements after correction for crystal fractionation to $\mathrm{Mg} \#=0.72$. Such correction highlights major element compositions of the parental melts when they are in equilibrium with mantle mineralogy prior to low pressure crystallization. These significant correlations suggest that the observed lava compositional variations in major elements, as well as in trace elements and isotopes, are inherited from fertile mantle sources. The enriched mantle component must have higher $\mathrm{Al}_{2} \mathrm{O}_{3}$, $\mathrm{Na}_{2} \mathrm{O}$ and $\mathrm{K} / \mathrm{Ti}$, moderate $\mathrm{TiO}_{2}$, and lower $\mathrm{CaO}, \mathrm{FeO}, \mathrm{MgO}$ (low $\mathrm{FeO}$ means low $\mathrm{MgO}$ at a given $\mathrm{Mg \#}$ ) and $\mathrm{CaO} / \mathrm{Al}_{2} \mathrm{O}_{3}$ than the depleted matrix. $\mathrm{P}_{72}$ and $\mathrm{K}_{72}$ also define positive trends on such plots (not shown). No trend is observed for $\mathrm{SiO}_{2}$.

\subsection{Correlations of isotopic ratios with measured $\mathrm{CaO}$ and $\mathrm{MgO}$ contents}

Fig. 7 shows that measured major element oxide contents of seamount lavas such as $\mathrm{MgO}$ and $\mathrm{CaO}$ (also $\mathrm{TiO}_{2}$ and $\mathrm{Na}_{2} \mathrm{O}$; see the Background Data Set $^{1}$ ) exhibit scattered yet significant correlations with radiogenic isotopes (the three HIMUlike samples are excluded from these plots). Incompatible element ratios such as $[\mathrm{La} / \mathrm{Sm}]_{\mathrm{N}}$ and $[\mathrm{Sm} / \mathrm{Yb}]_{\mathrm{N}}$ also correlate with these oxides (not

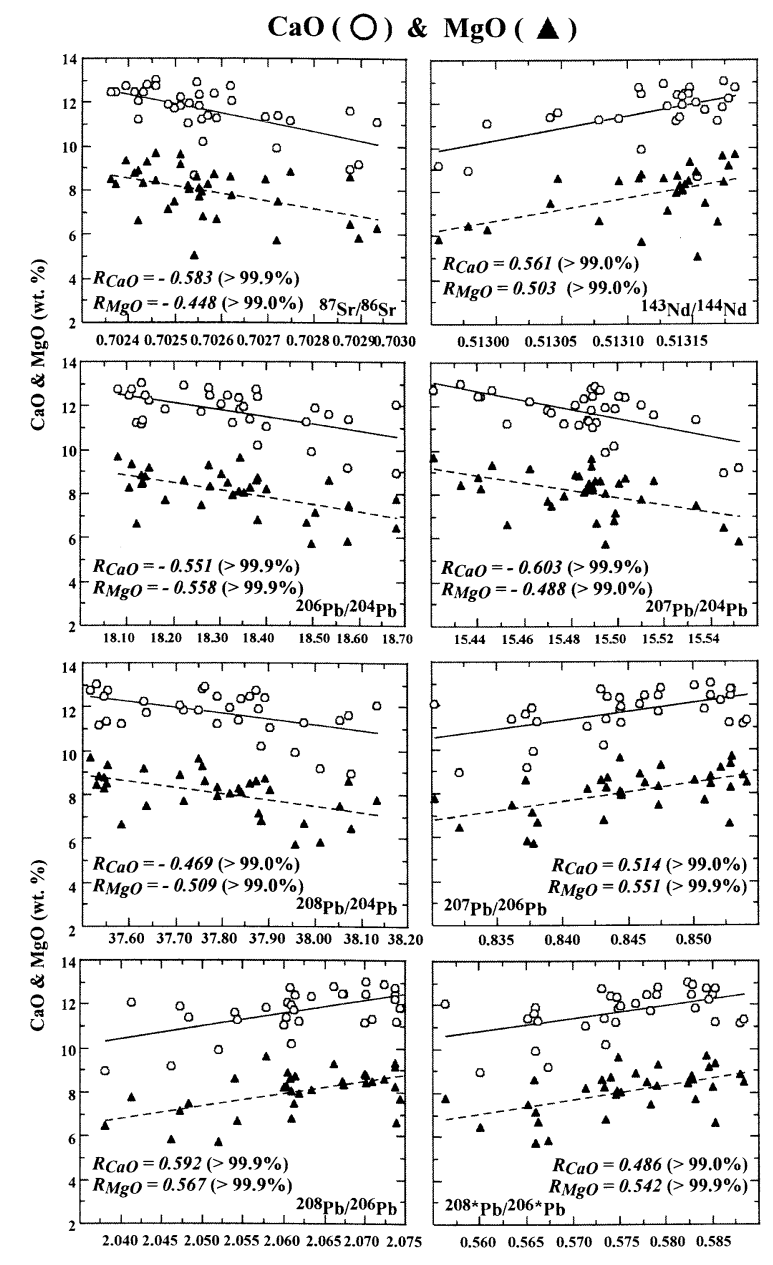

Fig. 7. Plots of $\mathrm{Sr}-\mathrm{Nd}-\mathrm{Pb}$ isotopic ratios with measured $\mathrm{MgO}$ and $\mathrm{CaO}$ contents in seamount lavas. These significant correlations suggest that processes such as mantle melting, crystallization, magma mixing etc. cannot entirely erase the source signatures. Note that the three HIMU-like samples are not plotted (see Fig. 5). More plots can be found in the Background Data Set ${ }^{1}$.

shown). These observations reinforce the conclusion from Fig. 6 that what we see in the mantlederived melts reflect, to a large extent, what is present in the mantle source [13]. It is possible that primary mantle melts parental to enriched lavas may have much less $\mathrm{MgO}$ than those depleted lavas $[39,40]$. For example, if the enriched source component were recycled oceanic crust (eclogites), they would have lower $\mathrm{MgO}$ (and higher $\mathrm{TiO}_{2}$ and $\mathrm{Na}_{2} \mathrm{O}$ ) than the peridotitic ma- 
trix. However, this recycled crust must have high, not low, $\mathrm{CaO}$ relative to the peridotitic matrix. Thus, an alternative explanation is needed.

We stress that the correlations in Fig. 7 provide additional information on how enriched melts derived from an enriched source affect magma evolution. Enriched melts have radiogenic $\mathrm{Sr}$ and $\mathrm{Pb}$, unradiogenic $\mathrm{Nd}$, and higher abundances of progressively more incompatible elements (Figs. 4-6) including alkalis and volatiles (e.g., $\mathrm{H}_{2} \mathrm{O}$ and $\mathrm{CO}_{2}$ etc.). These latter constituents are known to lower both the liquidus and solidus temperatures of silicate melts. Consequently, enriched melts cool to a lower liquidus temperature and crystallize to a greater extent (thus lower $\mathrm{MgO}$ and $\mathrm{CaO}$ ) than depleted melts before solidification. The important implication is that the data trends of many MORB suites on $\mathrm{MgO}$ variation diagrams do not represent true liquid lines of descent originating from any particular parent melt, but instead represent composite trends defined by individual melts with their own evolution paths and histories as a function of major element compositions and volatile contents of their respective parents. Therefore, parameters such as $\mathrm{Na}_{8}, \mathrm{Fe}_{8}$ and $\mathrm{Ca}_{8} / \mathrm{Al}_{8}$ etc. derived from $\mathrm{MgO}$ variation diagrams of sample suites that show source heterogeneities may not necessarily reflect parental values of the elements. Therefore, caution is necessary when using these parameters (see Figs. 6 and 7) to calculate the extent and depth of melting. Average values of these parameters over some geographic scale may only be meaningful for regional comparisons $[12,13]$.

\section{Discussion}

\subsection{Some conclusions}

Both axial and seamount volcanisms share a common heterogeneous mantle source beneath the fast-spreading EPR (Figs. 2 and 3), but seamount lavas provide more faithful information about the nature of the source than axial lavas. This heterogeneous source is characterized by volumetrically small but wide spread enriched material as physically distinct lithologies dispersed in a depleted peridotite matrix prior to the major melt events [1,2]. The enriched lithologies are characterized by radiogenic $\mathrm{Sr}$ and $\mathrm{Pb}$, unradiogenic $\mathrm{Nd}$, and are enriched in incompatible elements, more so in the more incompatible elements than in the less incompatible ones, suggesting that these enriched lithologies are of magmatic origin (Figs. 4-6). The depleted matrix is poor in all incompatible elements, has unradiogenic $\mathrm{Sr}$ and $\mathrm{Pb}$, and radiogenic $\mathrm{Nd}$ (Figs. 4-6). Melting to variable extents of such composite lithologies or melting to similar extents of a mantle containing variable proportions of the two lithologies result in melting-induced mixing relationships in geochemical diagrams [1,2] (Figs. 4-6). The actual enriched lithologies must, therefore, be more enriched than the most enriched lavas, and the depleted matrix must be more depleted than can be inferred from the most depleted lavas. We propose that the Garrett transform lavas (Fig. 4) $[12,32]$ best reflect the depleted matrix.

The time when these two lithologies were physically juxtaposed is unknown. However, both lithologies must be ancient and have developed their trace element and isotopic characteristics independently for some time ( $>1 \mathrm{Ga}$ ) because of coupled correlations of radiogenic isotopes with major and trace elements (Figs. 4-7). Fig. 8 demonstrates these coupled correlations between $\mathrm{Sr}-\mathrm{Nd}-\mathrm{Pb}$ isotopes and incompatible element abundances with the correlation coefficients progressively better for more incompatible elements. Major element systematics in lavas in the northern EPR region are to a large extent inherited from a heterogeneous fertile source. MORB major element data must be used with caution $[2,13,15]$ when interpreting the extent and depth of melting.

\subsection{Inferences}

If enriched and depleted lithologies of the fertile mantle source are both ancient, then the ancient process or processes that led to the formation of the enriched lithologies must not only produce enriched trace element signatures, which with time produces enriched isotopic signatures, but also must create the major element characteristics of the enriched lithologies seen in Fig. 6 (i.e., high 


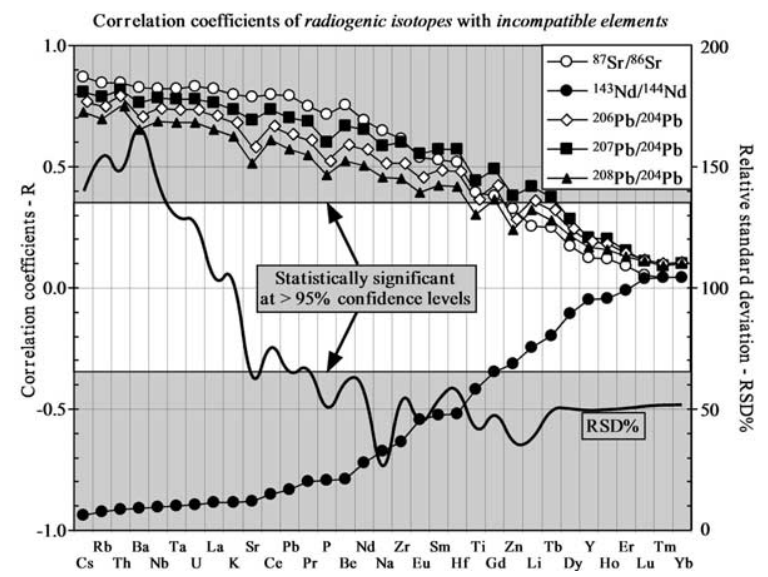

Fig. 8. Correlation coefficients ( $R$-values; left axis) of $\mathrm{Sr}-$ $\mathrm{Nd}-\mathrm{Pb}$ isotopic ratios with incompatible element abundances of seamount lavas are plotted in the order of decreasing absolute $\mathrm{R}$ values with ${ }^{143} \mathrm{Nd} /{ }^{144} \mathrm{Nd}$ from left to the right. Note that this order is similar to the decreasing order of relative elemental incompatibility determined by $X / Y-X$ plots [1] and the variability in terms of $\mathrm{RSD} \%$ (right axis). These correlations demonstrate the significant coupling between isotopes and trace elements, and the ancient nature of both the depleted and enriched source materials.

$\mathrm{Al}_{72}, \mathrm{Na}_{72}$ and $\mathrm{K} / \mathrm{Ti}$, moderate $\mathrm{Ti}_{72}$ and low $\mathrm{Ca}_{72}$, $\mathrm{Fe}_{72}$ and $\mathrm{Ca}_{72} / \mathrm{Al}_{72}$ ). As the correlations of isotopes with the abundances of incompatible elements are progressively better for the more incompatible elements (Fig. 8), the origin of the enriched lithologies must be magmatic. Because isotopes correlate well with $\mathrm{Zr} / \mathrm{Hf}, \mathrm{Nb} / \mathrm{Ta}, \mathrm{Rb} /$ $\mathrm{Cs}, \mathrm{Nb} / \mathrm{U}$ and $\mathrm{Ce} / \mathrm{Pb}$ (Fig. 5), the inferred magmatic processes must also fractionate these paired elements that have been thought to be geochemically similar. We thus infer that the magmatic processes might be very low degree (low F) melting because low $\mathrm{F}$ melts host highest abundances of incompatible elements, and because low $\mathrm{F}$ melting can effectively fractionate elements with only subtle differences in incompatibility (e.g., $\mathrm{Nb}$ vs. Ta and $\mathrm{Zr}$ vs. Hf etc.). The observation that low or sub-chondritic $\mathrm{Zr} / \mathrm{Hf}, \mathrm{Nb} / \mathrm{Ta}, \mathrm{Rb} / \mathrm{Cs}$, $\mathrm{Nb} / \mathrm{U}$ and $\mathrm{Ce} / \mathrm{Pb}$ ratios characterize the more depleted lavas [1] is also consistent with the low $\mathrm{F}$ processes. If the enriched lithologies (the product of the low F melts) have only slightly high or super-chondritic ratios, the residues of the low $\mathrm{F}$ melts must be low or sub-chondritic.

\subsection{The origin of enriched source component for E-MORB/OIB}

\subsubsection{The common perception}

Mantle source heterogeneity beneath ocean ridges is a well-known fact. The origin, history, and physical form of the enriched heterogeneities have been the subject of much research in the context of models of mantle circulation and ocean island basalt (OIB) genesis. It has been widely accepted that recycling of oceanic lithosphere is the primary mechanism that creates the enriched heterogeneities as 'blobs' or 'streaks' deep within the mantle that rise as 'plumes' to supply OIB $[1,2,41-51]$ and that the widespread E-type MORB reflect the presence of a diluted version of the OIB-type materials $[1,2,44,48-52]$ or less depleted OIB melting residues [2,53] in the subridge mantle. Also, a widely held view is that enriched component may occur as dikes/veins of low $\mathrm{F}$ melt metasomatism in the ambient depleted peridotitic matrix $[2,4,8,20,41,42,54-58]$ although there is little substantial discussion on how, where, and when such dikes/veins may have actually formed. Surveys of radiogenic isotopes $[43,59]$ and trace element systematics in oceanic basalts $[36,60]$, in particular the interpretations of intra-oceanic crust-mantle differentiation based on $\mathrm{Nb} / \mathrm{U}$ and $\mathrm{Ce} / \mathrm{Pb}$ ratios [36] have led to the prevailing view that recycled oceanic crust is the primary source for OIB and E-MORB.

\subsubsection{The problem}

Despite the above perception, recycled oceanic crust alone is inadequate to explain the enriched materials in the source regions of oceanic basalts. Oceanic crust is altered during its accretion at ocean ridges and pervasively weathered/hydrated subsequently on the seafloor. This crust that is atop the subducting slab endures the greatest extents of dehydration in subduction zones. Fluids released from this dehydration lowers the solidus of the overlying mantle wedge that melts to produce arc lavas, and the geochemical signatures of arc lavas largely reflect the signatures of subducting slab components [61-64], including sediments in places [65], particularly in oceanic settings with well developed back-arc basins [62-64]. As a re- 


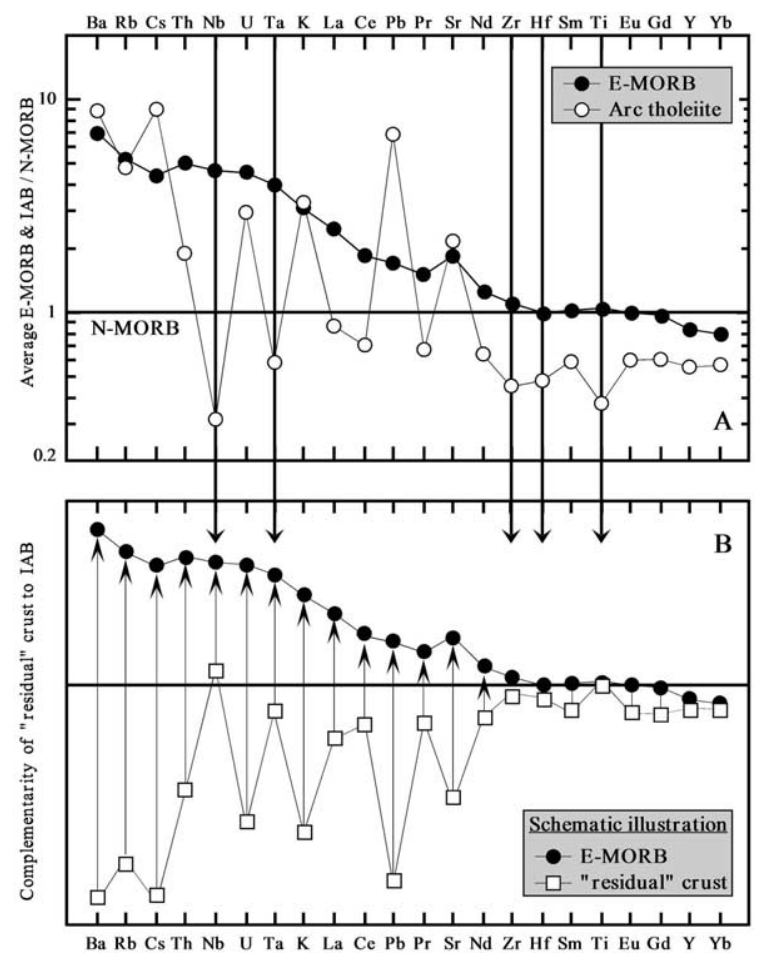

Fig. 9. (A) Average EPR E-MORB and average Tonga and Mariana tholeiite ([64] and unpublished data of Y. Niu) normalized to EPR N-MORB. (B) Schematic representation of the elemental signatures of a recycled oceanic crust that has passed through the subduction-zone dehydration reactions. Assuming HREEs are less affected by the dehydration (because of their relative immobility and weak incompatibility), the difference in both relative abundances and patterns between the recycled residual crust and E-MORB is extraordinary. Obviously, melting of recycled residual ocean crust with such trace element signatures cannot produce trace element signatures of E-MORB (and OIB). Some peculiar (ad hoc) processes would be required to refertilize the recycled crust with the relative extent of enrichments indicated by the length of the vertical arrows (see the Background Data Set ${ }^{1}$ for average EPR N- and E-type MORB).

sult, the residual subducted crust that has passed through the zones of subduction dehydration reactions should have geochemical signatures that are complementary to the signatures of arc lavas $[2,66]$. In other words, this residual crust should be relatively enriched in water-insoluble or immobile incompatible elements (e.g., Nb, Ta, Zr, Hf and $\mathrm{Ti}$ etc.) and highly depleted in water-soluble or mobile incompatible elements (e.g., Ba, Rb, Cs, $\mathrm{Th}, \mathrm{U}, \mathrm{K}, \mathrm{Sr}, \mathrm{Pb}$ etc.). It follows that if the recycled oceanic crust were geochemically responsible for OIB and E-MORB, then these latter basalts should be highly depleted in mobile incompatible elements. This is not observed. In fact, OIB and E-MORB are enriched in these mobile incompatible elements as well as immobile elements in spite of super-chondritic $\mathrm{Nb} / \mathrm{Th}$ and $\mathrm{Ta} / \mathrm{U}$ ratios [1,2].

Fig. 9A illustrates the argument by comparing the average EPR E-MORB and average Tonga and Mariana arc theoliites with average EPR NMORB. If the average N-MORB represent the mean geochemical signature of average ocean crust (this assumption is imprecise, but a useful reference point for this purpose because of the low abundances of incompatible elements in the cumulate lower ocean crust [67]), then the average E-MORB (also OIB) is progressively more enriched in more incompatible elements than $\mathrm{N}$ MORB, whereas the average arc tholeiite is depleted in rare earth elements (REEs), and significantly more so in immobile incompatible elements, but enriched in mobile incompatible elements. Fig. 9B shows schematically the geochemical signatures which average recycled residual oceanic crust should have as a result of subduction zone dehydration. Assuming HREEs are less affected by the subduction zone dehydration, then the contrast in both relative abundances (qualitatively) and patterns of incompatible elements between average E-MORB and the recycled residual crust is extraordinary. To melt or partially melt recycled ocean crust with such residual geochemical signatures cannot produce OIB or EMORB unless this residual crust were refertilized within the mantle by adding significant amounts of $\mathrm{Ba}, \mathrm{Rb}, \mathrm{Cs}, \mathrm{Th}, \mathrm{U}, \mathrm{K}, \mathrm{Pb}$ and $\mathrm{Sr}$ and lesser amounts of $\mathrm{Nb}$, Ta, LREEs, $\mathrm{Zr}$ and Hf, i.e., the reverse of subduction-zone dehydration. Such refertilization is ad hoc. Recycled terrigenous sediments would be enriched in these elements, but cannot explain the elevated $\mathrm{Ce} / \mathrm{Pb}$ and $\mathrm{Nb} / \mathrm{U}$ ratios in oceanic basalts $[2,36]$. The inadequacy of recycled oceanic crust as an enriched source for OIB has also been noticed very recently by Langmuir and co-workers [68]. 
Fig. 10. Schematic representations of our preferred model for the origin of the enriched component in the sources of oceanic basalts. (A) A general sketch of the origin of oceanic lithosphere at an ocean ridge, its thickening/growth due to heat loss with time, and its ultimate return into the deep mantle. (B) Mantle melting, melt migration, and ocean crust accretion at ocean ridges in a broader context emphasizing compositional stratification in the young lithosphere and the interface, a natural solidus, between the forming lithosphere and the sub-lithospheric LVZ. (C) Snapshot of the growing lithosphere. The oceanic lithosphere thickens with time through basal accretion due solely to heat loss to the surface. As the material to be accreted to the growing lithosphere with time comes from the LVZ, the interface between the lithosphere and the LVZ as a natural solidus representing the freezing front through which low $\mathrm{F}$ melts enriched in incompatible elements and volatiles originating in the LVZ is incorporated into the thickening lithosphere in the forms of trapped metasomatic melts or fine dikes or veins. The points labeled P1-P7 indicate the low F melts incorporated into the thickening lithosphere at different times and at different depths. While enriched materials incorporated at P1 would be the oldest, metasomatism or melt freezing can take place from P1 through P7 all at the same time. Therefore, the ages of the enriched heterogeneities in the lithosphere on a vertical section cannot be resolved in the time frame $(\sim 70-80$ Ma) before the lithosphere reaches its full thickness. These enriched heterogeneities would be similarly old when the recycled lithosphere returns to the source regions of oceanic basalts after $>1 \mathrm{Ga}$. (D) A stratigraphic list of the lithologies and their geochemical signatures of the recycled oceanic lithosphere after passing through the subduction zone dehydration reactions. Undoubtedly, the deep portions of the lithosphere are important reservoirs of volatiles and incompatible elements, particularly water-soluble elements. These metasomatized dikes/veins could be remobilized upward or assimilated/melted during intra-plate eruptions, giving rise to some extremely enriched lavas on many ocean islands.

\subsubsection{A preferred model}

If the enriched domains are volumetrically small lithologies of magmatic origin (Section 4.1), then these enriched lithologies could be dikes or veins formed by low F melts. That the enriched lithologies and depleted matrix both are old $(>1$ Ga) (Section 4.1) places constraints on their history. The remaining question is where and under what physical conditions such low F melts could be generated and solidified as dikes or veins within the dominantly depleted peridotitic matrix. Delamination of metasomatized continental lithosphere has been proposed in the literature as a mechanism to introduce enriched materials in
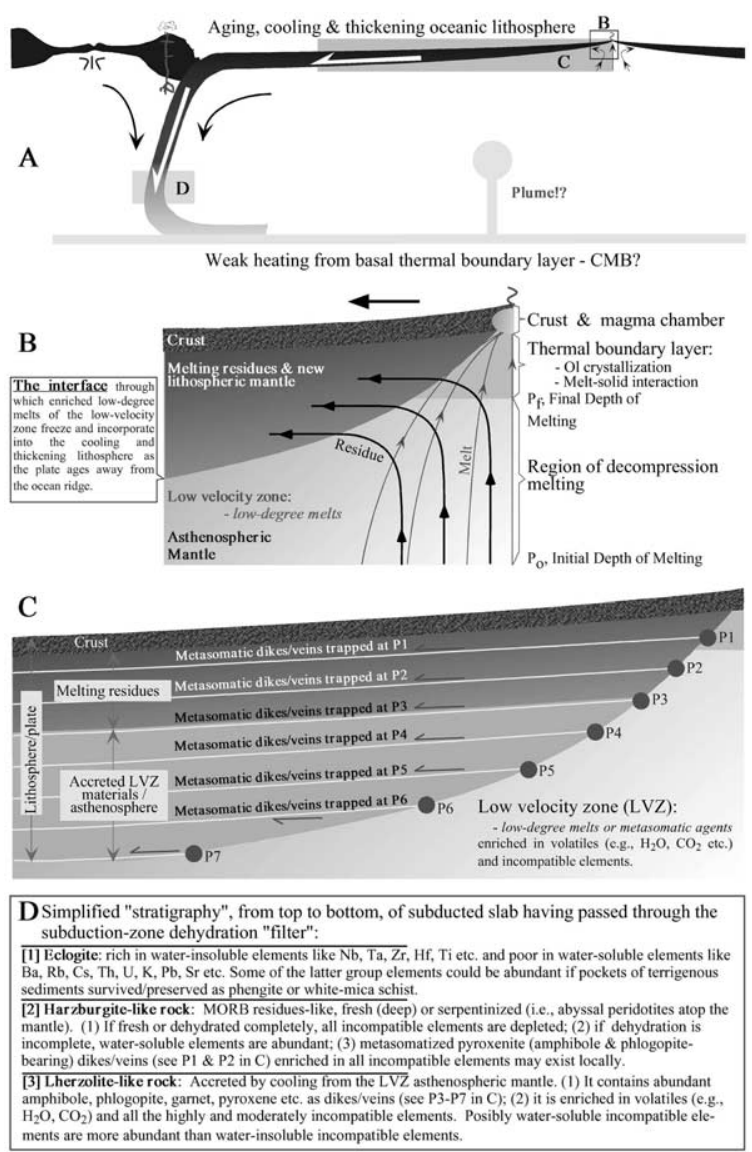

the source regions for oceanic basalts [69], but subcontinental lithosphere is buoyant and its recycling into deep mantle is physically difficult [70]. Subduction of oceanic lithosphere is, however, known to occur. Volumetrically small low degree melts enriched in volatiles and incompatible elements may inevitably develop in the low velocity zone (LVZ) and migrate upward and metasomatize the cooling and growing lithosphere as fine dikes and veins [2]. The interface between the LVZ and the cooling-induced thickening oceanic lithosphere is the effective solidus of the truly multi-component natural system where low $\mathrm{F}$ melt coexists with the thickening lithosphere. The LVZ has the lowest seismic velocity, the lowest viscosity in the mantle, and is thus the most likely region in the asthenosphere where fluid phases or small amounts of melt may exist. These fluid phases or low F melts are enriched in what- 
ever volatiles and incompatible elements present, both immobile and mobile incompatible elements. As oceanic lithosphere thickens due to cooling with time through basal accretion, these enriched low $\mathrm{F}$ melts are readily frozen and incorporated as 'metasomatic' dikes or veins in the thickening lithosphere at the LVZ-lithosphere interface. Consequently, although the topmost oceanic lithosphere may be highly depleted (MORB residues represented by abyssal peridotites), by the time of subduction its thickened deep portions are reservoirs of incompatible elements. It is less likely that these deep portions of the lithosphere (say $>60 \mathrm{~km}$ ) would undergo significant dehydration in subduction zones because of the thermal structure of the subducting slab. Reinjection of this metasomatized lithosphere into the mantle at subduction zones would contribute significantly to the enriched component in the sources of oceanic basalts [2]. Fig. 10 illustrates the concept and processes. Fully quantitative modeling, which is beyond the scope of the present contribution, is in progress (Niu and O'Hara, in preparation).

This low $\mathrm{F}$ melt metasomatism was conceived by Green [71], and discussed by many [41,42,54$58,72]$ as a possible cause of mantle heterogeneities. It is considered more seriously by Halliday et al. [73] to explain 'unusual' trace element ratios in central Atlantic OIB and MORB. These latter authors "propose that the source regions of these magmas are enriched by the introduction of small degree melts soon after the formation of the oceanic lithosphere". That is, the low F melts of unknown origin are young features because trace elements and isotopes are decoupled. While recent asthenospheric enrichments $[2,4,50]$ or lithospheric metasomatism [74] by mantle plumes have been postulated in many places, our concept of lithosphere freezing at the LVZ-lithosphere interface (Fig. 10) is of general significance that may be a widespread phenomenon occurring throughout much of the Earth's history [2]. For example, the enriched lithologies in the northern EPR mantle are old, and could reflect recycled ancient oceanic lithosphere. On the other hand, some extremely enriched lavas such as alkali basalts, nephelinite, basanite etc. on many ocean islands may in fact result from assimilation with or melting of [75] the metasomatized lithosphere, in which case the enriched materials would be young, younger than the lithosphere on which the islands rest. We suggest that the deep portions of oceanic lithosphere are important geochemical reservoirs in the context of intra-oceanic recycling and OIB and MORB genesis over much of the Earth's history.

\subsubsection{The composition of low $F$ melts and mineralogy of the metasomatized lithologies}

While the model presented above (Fig. 10) is internally consistent and explains the trace element systematics of E-MORB (also OIB with higher abundances of incompatible elements), verification requires answers to two important questions: (1) What is the major element composition of the low F melts? (2) What are the physical form and the mineralogy of the metasomatized lithologies within the deep portions of the oceanic lithosphere? Fig. 6 shows that the low F melts, as inferred from the data trends, must have high $\mathrm{Al}_{2} \mathrm{O}_{3}, \mathrm{Na}_{2} \mathrm{O}, \mathrm{K}_{2} \mathrm{O}$, moderate $\mathrm{TiO}_{2}$, and low $\mathrm{CaO}, \mathrm{FeO}, \mathrm{MgO}$ and low $\mathrm{CaO} / \mathrm{Al}_{2} \mathrm{O}_{3}-$ all of which are in excellent agreement with experimental results [76] and glass inclusions in mantle xenoliths [77,78]. The only difference lies in the $\mathrm{SiO}_{2}$ content. The experimental and natural low $\mathrm{F}$ melts have high $\mathrm{SiO}_{2}\left(\sim 52-65 \mathrm{wt}^{\%} \%\right)$, but E-MORB (and OIB), which are dominantly tholeiite, have low $\mathrm{SiO}_{2}(50 \pm 2 \mathrm{wt} \%)$. This is readily explained by the action of two processes: (a) a simple dilution effect and (b) olivine-orthopyroxene buffering during melt ascent in the mantle [13].

The enriched low F melts could well be trapped as interstitial 'glasses' by a process of 'non-modal' or 'cryptic' metasomatism [79], but fine dikes or veins may be the dominant lithologies. While pyroxenite or garnet-pyroxenite veins are present in many orogenic peridotites $[80,81]$, there may also be significant hydrous phases such as amphiboles and phlogopite because of the likely volatile enrichments in the LVZ, and because these latter phases host abundant water-soluble elements. These hydrous phases are widely observed in metasomatized lithospheric mantle [82,83], and stable in deep portions of aged oceanic lithosphere. The exact structural forms of these meta- 
somatized hydrous phases when subducted into the deep mantle are unknown, but their geochemical consequences when returned to the source regions of oceanic basalts are readily visualized as discussed above.

\subsubsection{A cautionary note}

The role of pyroxenite and garnet-pyroxenite veins as enriched lithologies in the sources of oceanic basalts - the currently prevailing view - can be questioned. Melting of such veins does not explain the enrichments of water-soluble elements in E-MORB (and OIB) (Fig. 9). Melting of such veins does not explain the major element compositions of E-MORB. E-MORB (at least the EPR type) have high $\mathrm{Na}_{2} \mathrm{O}$ and low $\mathrm{FeO}$, but experiments [84] demonstrate "melting of a mixed pyroxenite-peridotite mantle is likely to lead to liquids richer in $\mathrm{FeO}$ and $\mathrm{Na}_{2} \mathrm{O}$ ". While the super-chondritic $\mathrm{Nb} / \mathrm{Th}$ and $\mathrm{Ta} / \mathrm{U}$ ratios in oceanic basalts [1,2] favor recycled residual oceanic crust (eclogite) as a source component for EMORB (and OIB), this residual crust is inadequate (Fig. 9). Importantly, if subducting slabs indeed penetrate the $660 \mathrm{~km}$ discontinuity into the deep mantle as evidenced from the tomography [85], then the subducted residual crust would be $>2.5 \%$ denser than the peridotitic mantle at shallow lower mantle depths ( 800-1000 km depth) [86]. Such huge negative buoyancy will impede the rise of the recycled crust to the sources of oceanic basalts in the upper mantle. In this case, there would indeed be a hidden geochemical reservoir deep in the lower mantle $[66,87]$.

\section{Summary}

1. Near-EPR seamount and axial volcanisms share a common heterogeneous mantle source. The seamount lavas provide more faithful information than axial lavas about the nature of the mantle source heterogeneity.

2. The correlated variations among major elements, trace elements and $\mathrm{Nd}-\mathrm{Sr}-\mathrm{Pb}$ isotopes revealed by the seamount lavas indicate unequivocally the significance of source control on the observed lava compositional variations.
These source effects may be further modified by the effects of mantle melting and melt evolution at shallow levels. The similar, but weaker, correlation trends seen in the axial lavas emphasize the fact that EPR axial lava compositions also record source signatures.

3. Consequently, lava major element compositions should be used with caution to estimate the extent and depth of mantle melting unless there is evidence that lava major element composition is (a) totally independent of source composition, and is (b) clearly uncorrelated in any manner with the abundances and ratios of incompatible elements and radiogenic isotopes.

4. Recycled oceanic crust that has passed through the subduction dehydration reactions must be depleted in water-soluble incompatible elements such as $\mathrm{Ba}, \mathrm{Rb}, \mathrm{Cs}, \mathrm{Th}, \mathrm{U}, \mathrm{K}, \mathrm{Sr}, \mathrm{Pb}$ etc. Melting of residual recycled crust depleted in these elements cannot produce E-MORB and OIB which are enriched in these elements as well as in immobile incompatible elements.

5. We illustrate that deep portions of recycled oceanic lithosphere are the most likely storage of $\mathrm{Ba}, \mathrm{Rb}, \mathrm{Cs}, \mathrm{Th}, \mathrm{U}, \mathrm{K}, \mathrm{Sr}, \mathrm{Pb}$ as well as other incompatible elements as a result of low $\mathrm{F}$ melt metasomatism at the interface (the effective solidus) between the LVZ and the cooling and thickening oceanic lithosphere. This process may be a widespread phenomenon occurring throughout much of the Earth's history. The metasomatic products could be trapped interstitial melts or most likely fine dikes or veins.

6. Melting of pyroxenite or garnet-pyroxenite veins hosted in peridotites faces similar difficulty in explaining mobile incompatible elements in OIB and enriched MORB. We emphasize the presence and volumetric significance of hydrous phases such as amphiboles and phlogopite in hosting volatiles and these mobile incompatible elements.

7. Recycled deep portions of oceanic lithosphere are far more important than residual crust in creating compositional heterogeneity in the sources of oceanic basalts as reflected in EMORB and OIB. 


\section{Acknowledgements}

We thank US NSF and ONR for supporting the sampling program, and Australian Research Council grants to Y.N. for isotope data acquisition by M.R. and J.I.W. at The University of Queensland. Y.N. acknowledges full support by a UK NERC Senior Research Fellowship. Y.N. and M.J.O'H. thank Cardiff University for support. R.B. thanks NSF for support. We thank Fred Frey, Godfrey Fitton and Sally Gibson for extremely careful and constructive reviews. [BW]

\section{References}

[1] Y. Niu, R. Batiza, Trace element evidence from seamounts for recycled oceanic crust in the eastern Pacific mantle, Earth Planet. Sci. Lett. 148 (1997) 471-483.

[2] Y. Niu, K.D. Collerson, R. Batiza, J.I. Wendt, M. Regelous, The origin of E-type MORB at ridges far from mantle plumes: The East Pacific Rise at $11^{\circ} 20^{\prime}$, J. Geophys. Res. 104 (1999) 7067-7087.

[3] G.N. Hanson, C.H. Langmuir, Modelling of major elements in mantle systems using trace element approaches, Geochim. Cosmochim. Acta 42 (1978) 725-741.

[4] Y. Niu, D.G. Waggoner, J.M. Sinton, J.J. Mahoney, Mantle source heterogeneity and melting processes beneath seafloor spreading centres: the East Pacific Rise, $18^{\circ}-19^{\circ} \mathrm{S}$, J. Geophys. Res. 101 (1996) 2771127733.

[5] W.G. Melson, T.L. Vallier, T.L. Wright, G. Byerly, J. Nelen, Chemical diversity of abyssal volcanic glass erupted along Pacific Atlantic and Indian Ocean seafloor spreading centres. In: The Geophysics of the Pacific Ocean and its Margin: A Volume in Honour of George P. Woollard, Geophys. Monogr. 19 (1976) 351-368.

[6] J.-G. Schilling, M. Zajac, R. Evans, T. Johnston, W. White, J.D. Devine, R. Kingsley, Petrological and geochemical variations along the Mid-Atlantic Ridge from $29^{\circ} \mathrm{N}$ to $73^{\circ} \mathrm{N}$, Am. J. Sci. 283 (1983) 510-586.

[7] A. Zindler, H. Staudigel, R. Batiza, Isotope and trace element geochemistry of young Pacific seamounts: implications for the scale of mantle heterogeneity, Earth Planet. Sci. Lett. 70 (1984) 175-195.

[8] C.H. Langmuir, J.F. Bender, R. Batiza, Petrological and tectonic significance of the East Pacific Rise, $5^{\circ} 30^{\prime}-$ $14^{\circ} 30^{\prime} \mathrm{N}$, Nature 332 (1986) 422-426.

[9] E.M. Klein, C.H. Langmuir, Global correlations of ocean ridge basalt chemistry with axial depth and crustal thickness, J. Geophys. Res. 92 (1987) 8089-8115.

[10] Y. Niu, R. Batiza, An empirical method for calculating melt compositions produced beneath mid-ocean ridges: application for axis and off-axis (seamounts) melting, J. Geophys. Res. 96 (1991) 21753-21777.

[11] C.H. Langmuir, E.M. Klein, T. Plank, Petrological systematics of mid-ocean ridge basalts: Constraints on melt generation beneath ocean ridges. In: Mantle Flow and Melt Generation at Mid-Ocean Ridges, Geophys. Monogr. 71 (1992) 183-280.

[12] Y. Niu, R. Hékinian, Spreading rate dependence of the extent of mantle melting beneath ocean ridges, Nature 385 (1997) 326-329.

[13] Y. Niu, Mantle melting and melt extraction processes beneath ocean ridges: Evidence from abyssal peridotites, J. Petrol. 38 (1997) 1047-1074.

[14] D.W. Forsyth, Geophysical constraints on mantle flow and melt generation beneath mid-ocean ridges. In: Mantle Flow and Melt Generation at Mid-Ocean Ridges, Geophys. Monogr. 71 (1992) 1-66.

[15] Y. Niu, D. Bideau, R. Hékinian, R. Batiza, Mantle compositional control on the extent of mantle melting, crust production, gravity anomaly, ridge morphology, and ridge segmentation: A case study at the Mid-Atlantic Ridge $33-35^{\circ}$ N, Earth Planet. Sci. Lett. 286 (2001) 383 399.

[16] J.N. Natland, Partial melting of a lithologically heterogeneous mantle: Inferences from crystallization histories of magnesian abyssal tholeiites from the Siqueiros Fracture Zone. In: Magmatism in the Ocean Basins, Geol. Soc. Spec. Publ. 42 (1989) 41-70.

[17] F. Albarède, How deep do common basaltic magmas form and differentiate?, J. Geophys. Res. 97 (1992) 10,997-11,009.

[18] Y. Shen, D.W. Forsyth, Geochemical constraints on initial and final depth of melting beneath mid-ocean ridges, J. Geophys. Res. 100 (1995) 2211-2237.

[19] P.R. Castillo, E. Klein, J. Bender, C. Langmuir, S. Shirey, R. Batiza, W. White, Petrology and $\mathrm{Sr}, \mathrm{Nd}$, and $\mathrm{Pb}$ isotope geochemistry of mid-ocean ridge basalt glasses from the $11^{\circ} 45^{\prime} \mathrm{N}$ to $15^{\circ} 00^{\prime} \mathrm{N}$ segments of the East Pacific Rise, Geochem. Geophys. Geosyst. 1 (2000) 1999GC000024.

[20] C.C. Lundstrom, D.E. Sampson, M. Perfit, J. Gill, Q. Williams, Insights into MORB petrogenesis: U-series disequilibria from the Siqueiros Transform, Lamont Seamounts and East Pacific Rise, J. Geophys. Res. 104 (1999) 13035-13048.

[21] M.M. Hirschmann, E.M. Stolper, A possible role for garnet pyroxenite in the origin of the 'garnet signature' in MORB, Contrib. Mineral. Petrol. 124 (1996) 185-208.

[22] M.M. Hirschmann, M.S. Ghiorso, M. Stolper, Calculation of peridotite partial melting from Thermodynamic models of minerals and Melts. II. Isobaric variations in melts near the solidus and owing to variable source composition, J. Petrol. 40 (1999) 297-313.

[23] M.J. O'Hara, Importance of the 'shape' of the melting regime during partial melting of the mantle, Nature 314 (1985) 58-62.

[24] Y. Niu, R. Batiza, Extreme mantle source heterogeneities beneath the northern East Pacific Rise - Trace element 
evidence from near-ridge seamounts, Proc. 30th ICG 15 (1997) 109-120.

[25] M.J. O'Hara, Geochemical evolution during fractional crystallisation of a periodically refilled magma chamber, Nature 266 (1977) 503-507.

[26] J.M. Sinton, R.S. Detrick, Mid-ocean ridge magma chambers, J. Geophys. Res. 97 (1992) 197-216.

[27] R. Batiza, Y. Niu, J.L. Karsten, W. Boger, E. Potts, L. Norby, R. Butler, Steady and non-steady state magma chambers below the East Pacific Rise, Geophys. Res. Lett. 23 (1996) 221-224.

[28] R. Batiza, D. Vanko, Petrology of young Pacific seamounts, J. Geophys. Res. 89 (1984) 11235-11260.

[29] R. Batiza, Y. Niu, W.C. Zayac, Chemistry of seamounts near the East Pacific Rise implications for the geometry of sub-axial mantle flow, Geology 18 (1990) 1122-1125.

[30] R. Batiza, Y. Niu, Petrology and magma chamber processes at the East Pacific Rise $\sim 9^{\circ}$ N, J. Geophys. Res. 97 (1992) 6779-6797.

[31] M. Regelous, Y. Niu, J.I. Wendt, R. Batiza, A. Greig, K.D. Collerson, An $800 \mathrm{ka}$ record of the geochemistry of magmatism on the East Pacific Rise at $10^{\circ} 30^{\prime} \mathrm{N}$ : Insights into magma chamber processes beneath a fastspreading ocean ridge, Earth Planet. Sci. Lett. 168 (1999) 45-63.

[32] J.I. Wendt, M. Regelous, Y. Niu, R. Hékinian, K.D. Collerson, Geochemistry of lavas from the Garrett Transform Fault: insights into mantle heterogeneity beneath the eastern Pacific, Earth Planet. Sci. Lett. 173 (1999) 271-284.

[33] M.J. O'Hara, Are oceanic basalts primary magmas?, Nature 220 (1968) 683-686.

[34] D. Walker, T. Shibata, S.E. DeLong, Abyssal tholeiites from the Oceanographer Fracture Zone, II, Phase equilibria and mixing, Contrib. Mineral. Petrol. 70 (1979) 111125.

[35] T.L. Grove, R.J. Kinzler, W.B. Bryan, Fractionation of mid-ocean ridge basalt (MORB), In: Mantle Flow and Melt Generation at Mid-Ocean Ridges, Geophys. Monogr. 71 (1992) 281-310.

[36] A.W. Hofmann, K.P. Jochum, M. Seufert, W.M. White, $\mathrm{Nb}$ and $\mathrm{Pb}$ in oceanic basalts: new constraints on mantle evolution, Earth Planet. Sci. Lett. 79 (1986) 33-45.

[37] T.H. Green, J.D. Blundy, J. Adam, G.M. Yaxley, SIM determination of trace element partition coefficients between garnet, clinopyroxene and hydrous basalgic liquids at $2-7.5 \mathrm{GPa}$ and $1080-1200^{\circ} \mathrm{C}$, Lithos 53 (2000) 165-187.

[38] J. Blundy, B. Wood, Prediction of crystal-melt partition coefficients from elastic moduli, Nature 372 (1994) 452-454.

[39] P.D. Asimow, M.M. Hirschmann, E.M. Stolper, Calculation of peridotite partial melting from thermodynamic models of minerals and melts, IV. Adiabatic decompression and the composition and mean properties of midocean ridge basalts, J. Petrol. 42 (2001) 963-998.

[40] I.H. Campbell, The mantle's chemical structure: Insights from the melting products of mantle plumes. In: The Earth's Mantle - Composition, Structure and Evolution,
Cambridge University Press, Cambridge, 1998, pp. 259310.

[41] S.-s. Sun, W.F. McDonough, Chemical and isotopic systematics in ocean basalt: Implication for mantle composition and processes, In: Magmatism in the ocean Basins, Geol. Soc. Spec. Publ. 42 (1989) 313-345.

[42] S.-s. Sun, G.N. Hanson, Origin of Ross Island basanitoids and limitations upon the heterogeneity of mantle sources for alkali basalts and nephelinites, Contrib. Mineral. Petrol. 52 (1975) 77-106.

[43] W.M. White, A.W. Hofmann, $\mathrm{Sr}$ and $\mathrm{Nd}$ isotope geochemistry of oceanic mantle evolution, Nature 296 (1982) 821-825.

[44] C.J. Allègre, B. Hamelin, B. Dupré, Statistical analyses of isotopic ratios in MORB: the mantle blob cluster model in the convective regime of the mantle, Earth Planet. Sci. Lett. 71 (1984) 71-84.

[45] C.J. Allègre, D.L. Turcotte, Implications of a two-component marble-cake, Nature 323 (1986) 123-127.

[46] J.G. Fitton, D. James, Basic volcanism associated with intraplate linear features, Phil. Trans. R. Soc. London 317 (1986) 253-266.

[47] A. Zindler, S. Hart, Chemical geodynamics, Annu. Rev. Earth Planet. Sci. 14 (1986) 493-571.

[48] A.D. Saunders, M.J. Norry, J. Tarney, Origin of MORB and chemically-depleted mantle reservoirs: Trace element constraints, J. Petrol. Spec. Issue (1988) 415-445.

[49] B.L. Weaver, The origin of ocean island basalt end-member compositions: Trace element and isotopic constraints, Earth Planet. Sci. Lett. 104 (1991) 381-397.

[50] J.J. Mahoney, J.M. Sinton, D.M. Kurz, J.D. Macdougall, K.J. Spencer, G.W. Lugmair, Isotope and trace element characteristics of a super-fast spreading ridge: East Pacific Rise, $13-23^{\circ} \mathrm{S}$, Earth Planet. Sci. Lett. 121 (1994) 173-193.

[51] R.N. Thompson, G.L. Hendry, S.J. Parry, An assessment of the relative roles of crust, mantle in magma genesis: An elemental approach, Phil. Trans. R. Soc. London A310 (1984) 549-590.

[52] B. Dupré, C.J. Allègre, $\mathrm{Pb}-\mathrm{Sr}$ isotope correlation in Indian Ocean basalts and mixing phenomena, Nature 303 (1983) 142-146.

[53] J. PhippsMorgan, W.J. Morgan, Two-stage melting and the geochemical evolution of the mantle: a recipe for mantle plum-pudding, Earth Planet. Sci. Lett. 170 (1999) 215-239.

[54] D. McKenzie, Some remarks on the movement of small melt fractions in the mantle, Earth Planet. Sci. Lett. 95 (1989) 53-72.

[55] G.N. Hanson, Geochemical evolution of the sub oceanic mantle, J. Geol. Soc. London 134 (1977) 235-253.

[56] A. Prinzhofer, E. Lewin, C.J. Allègre, Stochastic melting of the marble-cake mantle: evidence from local study of the East Pacific Rise at $12^{\circ} 50^{\prime} \mathrm{N}$, Earth Planet. Sci. Lett. 92 (1989) 189-206.

[57] D.A. Wood, A variably veined suboceanic upper mantle Genetic significance for mid-ocean ridge basalts from geochemical evidence, Geology 7 (1979) 499-503. 
[58] A.P. LeRoex, H.J.B. Dick, A.L. Erlank, A.M. Reid, F.A. Frey, S.R. Hart, Geochemistry, mineralogy and petrogenesis of lavas erupted along the Southwest Indian Ridge between the Bouvet Triple Junction and 11 degrees east, J. Petrol. 24 (1983) 267-318.

[59] A.W. Hofmann, W.M. White, Mantle plumes from ancient oceanic crust, Earth Planet. Sci. Lett. 57 (1982) 421-436.

[60] A.W. Hofmann, Chemical differentiation of the Earth: the relationship between mantle, continental crust, and oceanic crust, Earth Planet. Sci. Lett. 90 (1988) 297-314.

[61] J.A. Pearce, D.W. Peate, Tectonic implications of the composition of volcanic arc magmas, Annu. Rev. Earth Planet. Sci. 23 (1995) 251-285.

[62] J.P. Davidson, Deciphering mantle and crustal signatures in subduction zone magmatism. In: Subduction - Top to Bottom, Geophys. Monogr. 96 (1996) 251-264.

[63] J.W. Hawkins, Evolution of the Lau Basin - insights from ODP Leg 135, In: Active Margins and Marginal Basins of the Western Pacific, Geophys. Monogr. 88 (1995) 125174.

[64] A. Ewart, K.D. Collerson, M. Regelous, J.I. Wendt, Y. Niu, Geochemical evolution within the Tonga-KermadecLau arc-backarc system: The role of varying mantle wedge composition in space and time, J. Petrol. 39 (1988) 331-368.

[65] T. Plank, C.H. Langmuir, The chemical compositions of subducting sediments and its consequencews for the crust and mantle, Chem. Geol. 145 (1998) 325-394.

[66] W.F. McDonough, Partial melting of subducted oceanic crust and isolation of its residual eclogitic lithology, Phil. Trans. R. Soc. London A 335 (1991) 407-418.

[67] Y. Niu, T. Gilmore, S. Mackie, A. Greig, W. Bach, Mineral chemistry, whole-rock compositions and petrogenesis of ODP Leg 176 gabbros: Data and discussion, ODP Sci. Results, 176 (in press).

[68] K. Donnelly, C.H. Langmuir, S.L. Goldstein, A. Lagatta, The origin of alkali and ocean icland basalts: contradictions and solutions, EOS Trans. AGU, 82, Fall Meet. Suppl. (2001) F1402.

[69] D. McKenzie, R.K. O'Nions, The source regions of oceanic island basalts, J. Petrol. 36 (1995) 133-159.

[70] W.L. Griffin, S.Y. O'Reilley, C.G. Ryan, The composition and origin of subcontinental lithosphere, Geochem. Soc. Spec. Publ. 6 (1999) 241-258.

[71] D.H. Green, Composition of basaltic magmas as indicators of conditions of origin: Application to oceanic volcanism, Phil. Trans. R. Soc. London A268 (1971) 707-725.

[72] F.A. Frey, D.H. Green, Integrated models of basalt petrogenesis: a study of quartz tholeiites to olivine melilitites from South eastern Australia utilizing geochemical and experimental petrological data, J. Petrol. 3 (1978) 463-513.

[73] A.N. Halliday, D.-C. Lee, S. Tommasini, G.R. Davies, C.R. Paslick, J.G. Fitton, D.E. James, Incompatible trace elements in OIB and MORB source enrichment in the sub-oceanic mantle, Earth Planet. Sci. Lett. 133 (1995) 379-395.
[74] C. Class, S.L. Goldstein, R. Altherr, P. Bachèlery, The process of plume-lithosphere interactions in the ocean basins - the case of Grande Comore, J. Petrol. 39 (1988) 881-903.

[75] M.J. O'Hara, Volcanic plumbing and the space problem thermal and geochemical consequences of large-scale assimilation in ocean island development, J. Petrol. 39 (1998) 1077-1089.

[76] M.B. Baker, M.M. Hirschmann, M.S. Ghiorso, E.M. Stolper, Compositions of near-solidus peridotite melts from experiments and thermodynamic calculations, Nature 375 (1995) 308-311.

[77] P. Schiano, B. Bourdon, On the preservation of mantle information in ultramafic nodules: glass inclusions within minerals versus interstitial glasses, Earth Planet. Sci. Lett. 169 (1999) 173-188.

[78] P. Schiano, B. Bourdon, R. Clocchiatti, D. Massare, M.E. Varela, Y. Bottinga, Low-degree partial melting trends recorded in upper mantle minerals, Earth Planet. Sci. Lett. 160 (1988) 537-550.

[79] S.Y. O'Reilly, W.L. Griffin, Mantle metasomatism beneath western Victoria, Australia: I, Metasomatic processes in Cr-diopside lherzolites, Geochim. Cosmochim. Acta 52 (1988) 433-447.

[80] F.A. Frey, C.J. Suen, H. Stockman, The Ronda high temperature peridotite: Geochemistry and petrogenesis, Geochim. Cosmochim. Acta 49 (1985) 2469-2491.

[81] E. Takazawa, F.A. Frey, N. Shimizu, M. Obata, Whole rock compositional variations in an upper mantle peridotite (Horoman, Hokkaido, Japan): are they consistent with a partial melting process?, Geochim. Cosmochim. Acta 64 (2000) 695-716.

[82] M. Gregoire, B.N. Moine, S.Y. O’Reilly, J.Y. Cottin, A. Giret, A Trace element residence and partitioning in mantle xenoliths metasomatized by highly alkaline, silicateand carbonate-rich melts (Kerguelen Islands, Indian Ocean), J. Petrol. 41 (2000) 477-509.

[83] D.A. Ionov, W.L. Griffin, S.Y. Oreilly, Volatile-bearing minerals and lithophile trace elements in the upper mantle, Chem. Geol. 141 (1997) 153-184.

[84] M.M. Hirschmann, M.B. Baker, E.M. Stolper, Partial melting of mantle pyroxenite, EOS Trans. AGU, 76, Fall Meet. Suppl. (1995) 696.

[85] R. van der Hilst, Evidence for deep mantle circulation from global tomography, Nature 386 (1997) 237-246.

[86] S. Ono, E. Ito, T. Katsura, Mineralogy of subducted basaltic crust (MORB) from 25 to $37 \mathrm{GPa}$, and chemical heterogeneity of the lower mantle, Earth Planet. Sci. Lett. 190 (2001) 57-63.

[87] R.L. Rudnick, M. Barth, I. Horn, W.F. McDonough, Rutile-bearing refractory eclogite: Missing link between continents and depleted mantle, Science 287 (2000) 278 281.

[88] W. Todt, R.A. Cliff, A. Hanser, A.W. Hofmann, Evaluation of a ${ }^{202} \mathrm{~Pb}-{ }^{205} \mathrm{~Pb}$ double spike for high-precision lead isotope analysis, In: Earth Processes: Reading the Isotopic Code, Geophys. Monogr. 95 (1996) 429-437. 